Article

\title{
Impact of Changes in the Required Thermal Insulation of Building Envelope on Energy Demand, Heating Costs, Emissions, and Temperature in Buildings
}

\author{
Walery Jezierski ${ }^{1}$, Beata Sadowska ${ }^{1}$ (D) and Krzysztof Pawłowski ${ }^{2, *(D)}$ \\ 1 Faculty of Civil Engineering and Environmental Sciences, Bialystok University of Technology, \\ Wiejska Street 45E, 15-351 Bialystok, Poland; w.jezierski@pb.edu.pl (W.J.); b.sadowska@pb.edu.pl (B.S.) \\ 2 Faculty of Civil and Environmental Engineering and Architecture, UTP University of Science and Technology, \\ 7 Kaliskiego Street, 85-796 Bydgoszcz, Poland \\ * Correspondence: krzypaw@utp.edu.pl
}

check for updates

Citation: Jezierski, W.; Sadowska, B.; Pawłowski, K. Impact of Changes in the Required Thermal Insulation of Building Envelope on Energy Demand, Heating Costs, Emissions, and Temperature in Buildings.

Energies 2021, 14, 56. https://dx.doi. org/10.3390/en14010056

Received: 2 November 2020 Accepted: 19 December 2020 Published: 24 December 2020

Publisher's Note: MDPI stays neutral with regard to jurisdictional claims in published maps and institutional affiliations.

Copyright: () 2020 by the authors. Licensee MDPI, Basel, Switzerland. This article is an open access article distributed under the terms and conditions of the Creative Commons Attribution (CC BY) license (https: / / creativecommons.org/ licenses/by/4.0/).

\begin{abstract}
Various methods can be used to reduce energy consumption in buildings. One of them is the tightening of energy requirements, which, like other methods, cannot result in a worsening of the indoor environmental quality. The article presents a study on the impact of changes in the thermal insulation of the building envelope on the energy demand, heating costs, and emissions. Mathematical models of the dependence of the index of annual usable energy demand for heating $\left(E U_{H}\right)$ of a residential house on the thermal transmittance coefficients $\left(U_{i}\right)$ of selected building elements were developed. Values of $U_{i}$ were adopted at three levels, corresponding to the maximum required values-as approved in Polish law for the periods from 2014, 2017, and 2021. The analyses were conducted for the location of the building in three of the five climate zones of Poland. It turned out that the differences in the energy demand in various locations in Poland amount to $32.6 \%$. The change in $U_{i}$ in the analyzed period causes a decrease of $E U_{H}$ by almost $27 \%$. Financial savings and a reduction of emissions strongly depend on the fuel used in the building. Increasing the level of thermal insulation of walls increases the perceptible temperature in rooms by $1.2-1.5 \%$.
\end{abstract}

Keywords: thermal transmittance coefficient; building envelope; the index of annual usable energy demand for heating; deterministic mathematical model; financial savings; reduction of harmful emissions; perceptible temperature

\section{Introduction}

The construction market is responsible for the consumption of around $40 \%$ of the energy produced in the European Union (EU) and 37\% of pollutant emissions [1]. This sector is therefore crucial to achieving the EU's energy and environmental objectives.

One of the methods to reduce the energy demand of buildings, used in Polish legislation, is the legal adoption of increasingly stringent requirements for the thermal transmittance coefficient of the building envelope. Initially, these requirements were included in the standards (Table 1). Since 1997, they have been moved to the Regulation on the Technical Conditions that buildings and their location should meet. The latest amendment to this legal document, regarding the thermal protection of buildings [2], entered into force on 1 January 2014. A gradual plan of tightening the requirements has been mapped out until 1 January 2021, when all new buildings should be nearly zero-energy buildings [1].

From the data presented in Table 1, it appears that-over the years-there has been a significant reduction in the required values of the analyzed parameter in Poland. As a result, in new buildings or when modernizing existing buildings, it is necessary to use an increasingly larger thickness of traditional insulation materials or to replace them with materials with a lower design thermal conductivity $\lambda(\mathrm{W} /(\mathrm{mK}))$. 
Table 1. Maximum required values of the thermal transmittance coefficient of the selected building envelope at room temperature $t_{i} \geq 16^{\circ} \mathrm{C}$ in Poland [2,3].

\begin{tabular}{|c|c|c|c|c|c|c|}
\hline \multirow{3}{*}{$\begin{array}{l}\text { Period of } \\
\text { Validity }\end{array}$} & \multirow{3}{*}{$\begin{array}{c}\text { Document } \\
\text { Constituting the Legal } \\
\text { Basis }\end{array}$} & \multicolumn{5}{|c|}{ Type of Building Envelope } \\
\hline & & External Walls & Roofs & $\begin{array}{l}\text { Windows and } \\
\text { Balcony Doors }\end{array}$ & Roof Windows & Doors \\
\hline & & \multicolumn{5}{|c|}{$U_{C(\max )}\left(\mathrm{W} /\left(\mathrm{m}^{2} \mathrm{~K}\right)\right)$} \\
\hline 1957-1964 & $\begin{array}{c}\mathrm{PN}-57 / \mathrm{B}-02405 \\
\text { (as a recommendation) }\end{array}$ & \multirow{3}{*}{$\begin{array}{l}1.16 \text { or } 1.42 \\
\text { (depending on } \\
\text { the climate } \\
\text { zone) }\end{array}$} & 0.87 & - & - & - \\
\hline 1964-1974 & PN-64/B-03404 & & 0.87 & - & - & - \\
\hline 1974-1982 & PN-74/B-03404 & & 0.70 & \multicolumn{2}{|c|}{$\begin{array}{c}\text { 2.0-5.8 (depending on the climate } \\
\text { zone) }\end{array}$} & $1.60-5.80$ \\
\hline 1982-1991 & PN-82/B-02020 & 0.75 & 0.45 & \multirow{3}{*}{$\begin{array}{l}2.0-2.6 \text { (depending } \\
\text { on the climate zone) }\end{array}$} & - & $1.10-5.60$ \\
\hline 1991-2002 & PN-91/B-02020 & $0.55-0.70$ & 0.30 & & - & 3.0 \\
\hline 2002-2008 & $\begin{array}{l}\text { Journal of laws of the } \\
\text { Republic of Poland, } \\
\text { 2002, no 7, Item } 690\end{array}$ & $0.30-0.50$ & 0.30 & & 2.00 & 2.60 \\
\hline 2009-2013 & $\begin{array}{l}\text { Journal of laws of the } \\
\text { Republic of Poland, } \\
2008 \text {, no 201, Item } 1238\end{array}$ & 0.30 & 0.25 & $1.70-1.80$ & 1.80 & 2.60 \\
\hline 2014-2016 & \multirow{3}{*}{$\begin{array}{l}\text { Journal of laws of the } \\
\text { Republic of Poland, } \\
\text { 2013, Item } 926\end{array}$} & 0.25 & 0.20 & 1.30 & 1.50 & 1.70 \\
\hline 2017-2019 & & 0.23 & 0.18 & 1.10 & 1.30 & 1.50 \\
\hline $\begin{array}{c}\text { since } 31 \\
\text { December } 2020\end{array}$ & & 0.20 & 0.15 & 0.90 & 1.10 & 1.30 \\
\hline
\end{tabular}

The large majority (94\%) of the United Nations Economic Commission for Europe (UNECE) countries have requirements for thermal insulation, including $U$-values [4]. However, the requirements for the quality of buildings in different countries, due to different climatic conditions, are difficult to compare. Stringent energy standards for one country may not be effective in another country. D'Agostino [5] noticed that an excessively high thickness of insulating material, even if it is in compliance with the current legislative requirements, can be disadvantageous in buildings characterized by great internal thermal loads or located in climatic contexts with mild winters and hot summers. The maximum $U$-values for selected building components in several countries with climatic conditions similar to Poland are presented in Table 2.

Table 2. Required values of the thermal transmittance coefficient of the selected building envelope in several countries $[6,7]$.

\begin{tabular}{ccccc}
\hline $\begin{array}{c}\text { Type of } \\
\text { Building } \\
\text { Envelope }\end{array}$ & $\begin{array}{c}\text { Germany (Since } \\
\text { 1 January 2016) }\end{array}$ & $\begin{array}{c}\text { Austria (Since } \\
\text { April 2019) }\end{array}$ & $\begin{array}{c}\text { Slovak } \\
\text { Republic (Since } \\
\text { 1 January 2016) }\end{array}$ & $\begin{array}{c}\text { Czech Republic } \\
\text { (Since } \\
\text { 1 January 2013) }\end{array}$ \\
\cline { 2 - 5 } & \multicolumn{4}{c}{ Required $\boldsymbol{U}$ Value $\left(\mathbf{W} /\left(\mathbf{m}^{\mathbf{2}} \mathbf{K}\right)\right)$} \\
\hline External walls & 0.28 & 0.35 & 0.22 & 0.30 \\
Roofs & 0.20 & 0.20 & 0.15 & 0.24 \\
Windows & 1.30 & 1.40 & 1.00 & 1.70 \\
Doors & 1.80 & 1.70 & 2.50 & 3.50 \\
\hline
\end{tabular}

The thermal quality of the building envelope has an impact on the energy demand for heating. Therefore, the authors of this study decided to determine how the tightening of standard requirements on the $U$-value in recent years in Poland reduces the $E U_{H}$ index. The experiment concerns single-family buildings, because they represent around $91 \%$ of the Polish residential building stock [8]. The number of building permits has also been 
increasing for several years. In 2018, 98,915 permits for the construction of new residential buildings were issued in Poland, which represents $50.4 \%$ of the total number of permits. In total, $94.7 \%$ of permits for residential buildings were permits for single-family designs. In $2018,93,714$ were issued, i.e., 3\% more than in 2017 (90,968 permits) and $13.1 \%$ more than in 2016 (82,852 permits) [9].

Statistical data confirm the significance of this group of buildings. According to [10], Europeans more often choose to live in single-family than in multi-family houses. In 2016, the share of persons living in houses ranged from almost 34\% in Spain to $93 \%$ in Ireland. In Poland, it matched the average for the EU-28 population, exceeding $57 \%$. More than half of the population in Poland (51.9\%) and Denmark (54.9\%) lived in detached houses, while this share rose to more than $60.0 \%$ in Romania (61.9\%), Hungary (62.8\%), and Slovenia $(65.5 \%)$, peaking at $71.0 \%$ in Croatia [10].

The structure of energy consumption in residential buildings in "EU-15" countries differs from the structure of its consumption in Poland. In both cases, the largest share is devoted to heating, but in EU countries, it accounts for about 57\% [11], while in Poland, it is as much as $65.1 \%$ [12]. Therefore, the problem with determining the energy demand for heating is significant.

The energy consumption in buildings located in Poland was discussed by Krawczyk and Sadowska [13]. The average heating energy consumption obtained for a group of single-family houses, located in the northeast region of Poland, with natural ventilation and after comprehensive thermomodernization, was $92 \mathrm{kWh} /\left(\mathrm{m}^{2}\right.$ year). These results were verified by long-term operational data. The use of a mechanical ventilation system with heat recovery in low-energy houses has allowed energy consumption for heating equal to $42 \div 53 \mathrm{kWh} /\left(\mathrm{m}^{2}\right.$ year $)$. These houses were built in the years 1999-2003, and in the following years, they were monitored in order to confirm their low energy consumption. Heat transfer coefficients of the building envelope were the following: external walls $-0.20 \mathrm{~W} /\left(\mathrm{m}^{2} \mathrm{~K}\right)$; pitched roof and ceiling under the attic $-0.18 \mathrm{~W} /\left(\mathrm{m}^{2} \mathrm{~K}\right)$; and window $-1.90 \mathrm{~W} /\left(\mathrm{m}^{2} \mathrm{~K}\right)$ and doors $-1.90 \mathrm{~W} /\left(\mathrm{m}^{2} \mathrm{~K}\right)$.

The authors of this article, in their previous research [14], developed deterministic mathematical models of the demand for usable energy for heating $Q_{H}$ of selected residential buildings in the climatic conditions of three cities-Szczecin, Lodz, and Zakopane-and made an attempt to estimate the energy effects caused by the changing of the $U_{i, \max }$ values of the building envelope, in force in Polish regulations from 1 January 2014; 1 January 2017, and 31 December 2020. The financial benefits of reducing the $Q_{H}$ for a natural gas-fired building were also estimated. It turned out that the change of the required $U_{i}$ values of selected building elements from the level that complies with Polish national regulations from 1. January 2014 to the one applicable from 1 January 2017 resulted in a decrease in $Q_{H}$ by nearly $1000 \mathrm{kWh}$ /year in Szczecin, by more than $1065 \mathrm{kWh} /$ year in Lodz, and $1288 \mathrm{kWh} /$ year in Zakopane. This resulted in financial benefits in the analyzed locations, respectively: EUR 43, 46, and 55 EUR. However, in the first stage of the research, the usable energy for heating the building was selected as the target function, which directly characterized only the selected object with a specific size of usable area and cubature.

Reducing fuel consumption for heating has a positive impact on the environment. First, it causes a decrease in greenhouse gas emissions (mainly $\mathrm{CO}_{2}$ into the atmosphere), largely responsible for the greenhouse effect, which ultimately leads to global warming. The reduction of $\mathrm{SO}_{\mathrm{x}}$ sulphur oxides emissions is also significant [15]. They arise from the process of burning sulfated fuels and lead to acidification of the atmosphere, which causes acid rain, which in turn causes soil degradation and pollution in forest ecosystems. Additionally, $\mathrm{NO}_{\mathrm{x}}$ nitrogen oxides formed at high temperatures in fuel combustion processes negatively affect the atmosphere by destroying the protective ozone layer in the stratosphere, which protects us from the harmful effects of ultraviolet UVA and UVB radiation. According to the latest available data [16], in 2017, Poland took the leading place among the $E U$ countries in terms of the amount of sulphur oxides emissions (583,000 tons) and, in the case of nitrogen oxides (804,000 tons), it was ranked fourth. Poland is also one 
of the largest GHG emitters. In 2017, these emissions amounted to over 400 million tons, of which $81 \%$ (337 million tons) was carbon dioxide. In $2018, \mathrm{CO}_{2}$ emissions per capita in Poland amounted to $8.36 \mathrm{t}$ and were higher than the EU-28 average and the world average value [17].

Unfortunately, the literature lacks the results of research estimating the energy, economic, and ecological effects of changes in the required $U$-value of all building envelopes in different locations of the building. The results of the authors' preliminary research are included in the mentioned publication [14]. However, this is an important issue, determining not only the final energy balance of the building but also the possible reduction of heating costs and negative environmental impact, so it is worth considering. The main research problem is the impact of the value of the thermal transmittance coefficients of the building envelope on the index of annual usable energy demand for heating, harmful emissions, and heating costs.

In this article, the authors decided to answer the question of what yields this reduction of $U_{\text {max }}$ by $0.03 \mathrm{~W} / \mathrm{m}^{2} \mathrm{~K}$ in two consecutive steps of tightening the requirements in the real conditions of buildings operation. Are the permissible values of this coefficient being changed too slowly? What effect do these changes have on the parameters of the internal environment influencing thermal comfort, which is one of the main factors responsible for high IEQ levels? As a function of the objective of this study, the index of annual usable energy demand for heating of a residential house was selected. It characterizes a whole class of similar objects. The authors also decided to examine what will be the differences in lowering this indicator for building heating in various locations in Poland, differing in climatic conditions. It is also planned to try to estimate the financial and environmental effects of changes in the required thermal insulation of the building envelope in similar buildings using different fuels in different climatic conditions.

In connection with the above, the purpose of the work is to examine the index of the annual demand for usable energy for heating of a selected single-family residential building located in different climatic zones of Poland: I: milder in Szczecin; III: national average, in Lodz; and V: more severe, in Zakopane, depending on the thermal transmittance coefficients of external walls $\left(U_{1}\right)$, flat roof $\left(U_{2}\right)$, windows and balcony doors $\left(U_{3}\right)$, roof windows $\left(U_{4}\right)$, and external doors $\left(U_{5}\right)$. All of the above were adopted at three levels corresponding to the maximum allowable values as approved in the Regulation on the Technical Conditions for the periods from 2014, 2017, and 2021. The influence of selected factors and various fuels on the cost of heating, reduction of pollutant emissions, and parameters influencing the thermal comfort of rooms were estimated.

\section{Materials and Methods}

\subsection{Method for Calculating the Index of Annual Demand for Usable Energy for Heating}

In the study, in accordance with the adopted objective, the utility energy demand indicator for heating and ventilation of the $E U_{H}$ building in question was selected as a function of goal $Y$. It is the quotient of the annual demand for usable energy for heating and ventilation $\left(Q_{H, n d}\right)$ and its heated area $\left(A_{f}\right)$. The $Q_{H, n d}$ values were calculated according to the algorithms for energy performance in Poland [18] in force since 2015. It includes the heat losses and gains that make up the building's energy balance, and are determined according to the Equations (1)-(9):

$$
\begin{gathered}
Q_{H, n d, s, n}=Q_{H, h t, s, n}-\eta_{H, g n, s, n} Q_{H, g n, s, n} \\
Q_{H, h t, s, n}=Q_{t r, s, n}+Q_{v e, s, n}, \\
Q_{t r, s, n}=H_{t r, s}\left(\theta_{i n t, s, H}-\theta_{e, n}\right) t_{\mathrm{m}}, \\
Q_{v e, s, n}=H_{v e, s}\left(\theta_{i n t, s, H}-\theta_{e, n}\right) t_{m}, \\
H_{t r, s}=\sum\left[b_{t r, i}\left(A_{i} U_{i}+\sum l_{i} \Psi_{i}\right)\right], \\
H_{v e, s}=\rho_{a} c_{a} \sum b_{v e, s} V_{v e, s}
\end{gathered}
$$




$$
\begin{gathered}
Q_{H, g n, s, n}=Q_{s o l, H}+Q_{i n t, H} \\
Q_{s o l, H}=\sum C_{i} A_{o i} I_{i} F_{s h, g l} F_{s h} g_{g l}, \\
Q_{i n t, H}=q_{i n t} A_{f} t_{m},
\end{gathered}
$$

The definition of the $E U_{H}$ index (Table 3) was provided for the extension of the method and block diagram of the calculations developed by the authors in [14].

\begin{tabular}{|c|}
\hline $\begin{array}{c}\text { Procedure for Calculating the Index of Annual Usable Energy Demand for Heating and } \\
\text { Ventilation }\end{array}$ \\
\hline Introduction of input variables $U_{1}, U_{2}, U_{3}, U_{4}, U_{5}$ \\
\hline $\begin{array}{l}\text { Introduction of permanent parameters } U_{i}, A_{i}, \Psi i, l_{i}, b_{t r, i}, \theta_{i n t, s, H}, \theta_{e, n}, t_{m}, A_{o i}, C_{i}, I_{i}, F_{s h, g l}, F_{s h}, g_{g l}, \\
\qquad q_{i n}, A_{f}, b_{v e, k}, V_{v e, s}\end{array}$ \\
\hline Calculation of heat losses by ventilation $H_{v e, s}, Q_{v, e, s, n}$ \\
\hline Calculation of heat losses by transmission $H_{t r, s}, Q_{t r, s, n}, Q_{H, h t, s, n}, Q_{H, n d, s, n}$ \\
\hline Calculation of heat gains $Q_{\text {sol }, H}, Q_{i n t, H}$ \\
\hline Calculation of the annual demand for usable energy for heating and ventilation $Q_{H, n d, s, n}$ \\
\hline $\begin{array}{l}\text { Determination of the index of annual energy demand for heating and ventilation } E U_{H}= \\
\qquad Q_{H, n d, s, n} / A_{f}\end{array}$ \\
\hline
\end{tabular}

Table 3. Block diagram for calculating the index of annual usable energy demand for heating and ventilation of a selected building $\left(\mathrm{kWh} /\left(\mathrm{m}^{2} \cdot\right.\right.$ year $\left.)\right)$ (own elaboration).

Based on the presented Equations (1)-(9) and methodology [18], the authors selected five input variables regarding the thermal quality of the envelope and developed an algorithm for calculating the index of the annual usable energy demand for heating (Table 3) when changing the values of selected factors according to the plan of the computational experiment.

\subsection{Characteristics of the Selected Residential Building}

The analyses were carried out on the example of a single-family residential building with a typical area and form for Polish conditions. It is a building with a simple structure (Figure 1), referring to the traditional style: one-story, without a basement, with a usable attic. The front elevation is oriented towards the north. The main building parameters are:

- $\quad$ Building development area: $105.32 \mathrm{~m}^{2}$;

- Total area: $162.48 \mathrm{~m}^{2}$;

- Usable area: $150.11 \mathrm{~m}^{2}$;

- Clear height of rooms: $2.70 \mathrm{~m}$;

- Volume: $690 \mathrm{~m}^{3}$.

The building has a rectangular shape with dimensions of $9.54 \mathrm{~m} \times 11.04 \mathrm{~m}$. It is made in traditional technology, with a wooden gable roof with a $45^{\circ}$ angle, covered with ceramic tiles. The foundation benches are reinforced concrete, foundation walls of concrete blocks, external walls of a 24-cmaerated concrete insulated from the outside with a layer of polystyrene, and the ceiling above the ground floor is reinforced concrete. The roof is insulated with mineral wool, and from the attic side gypsum plasterboard was used. The floor on the ground consists of a concrete foundation on gravel ballast, 10-cm-thick foamed polystyrene, PE film, and floor layers on a concrete foundation. Windows and external doors are made of PVC. Ventilation is natural.

It was assumed that the determination of the index of annual usable energy demand for heating $E U_{H}$ of a selected building will be made for three selected locations in Poland differing significantly in climatic conditions. 


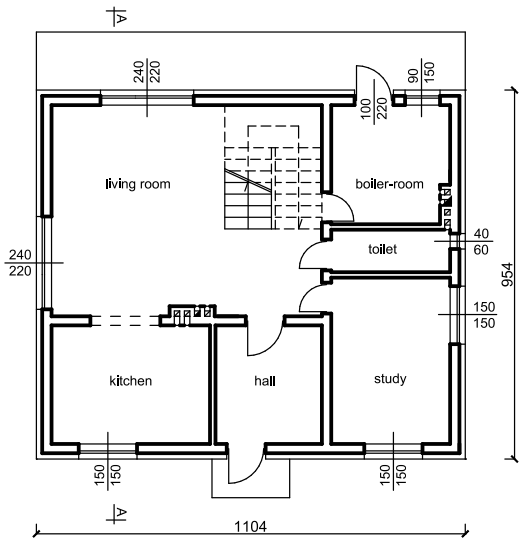

(a)

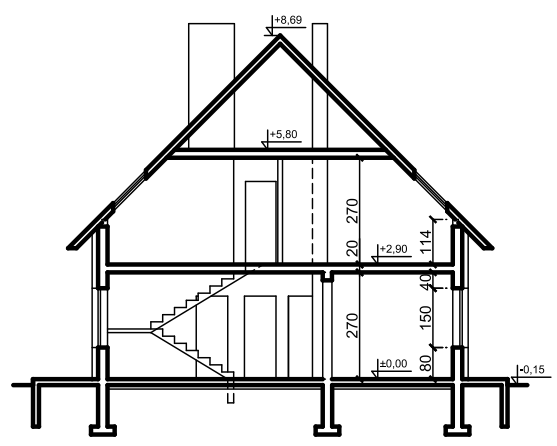

(c)

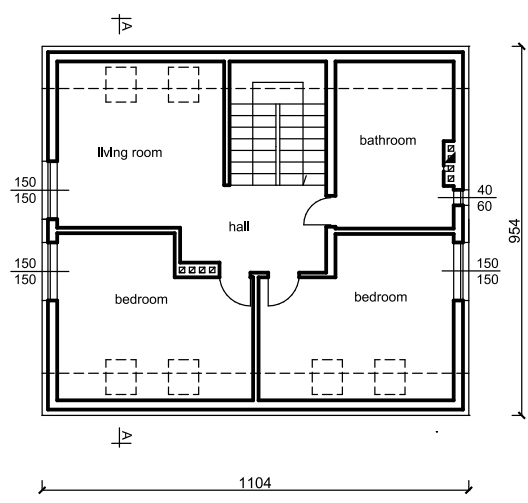

(b)

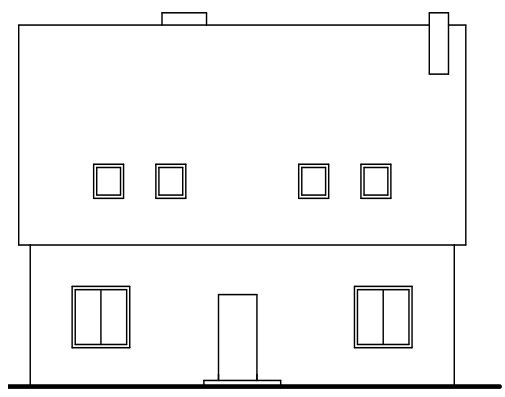

(d)

Figure 1. Scheme of the tested single-family house: (a) Ground floor plan; (b) Plan of heated attic; (c) Vertical section; (d) Front elevation (own elaboration).

\subsection{Mathematical Model of the Annual Usable Energy Demand Index for Heating of a Selected Residential Building}

As a research method, mathematical modeling was used, which allows mathematical relationships to describe the functioning of the tested object. Mathematical models are effective tools for performing analyses of the examined object, provided that the developed relationships are short and use the most relevant factors describing the examined process or property [19].

In the research, the index of annual usable energy demand for heating of the tested building $E U_{H}$ was chosen as a function $Y$, depending on the following thermal transmittance coefficients: of external walls $U_{1}$ (factor $X_{1}$ ), roof $U_{2}$ (factor $X_{2}$ ), windows and balcony doors $U_{3}\left(\right.$ factor $\left.X_{3}\right)$, roof windows $U_{4}$ (factor $\left.X_{4}\right)$, and external doors $U_{5}$ (factor $X_{5}$ ).

Unfortunately, the climatic factor mentioned in the study was not included in the model (as the sixth factor) because it is presented with a set of various climate indicators (Table 4), which are difficult to combine with a comprehensive indicator. Therefore, a decision was made to develop and compare three mathematical models of the dependence on five factors for each of the three groups of climatic conditions: group I-Szczecin (I climatic zone of Poland-the mildest conditions)-EU $U_{H I}\left(Y_{I, i}\right)$, group II-Lodz (III climatic zone of Poland-average national conditions))-EU $U_{H I I}\left(Y_{I I, i}\right)$, and group III-Zakopane (V climatic zone of Poland, the most severe conditions))-EU $U_{H I I I}\left(Y_{I I I, i}\right)$. 
Table 4. Averaged climate characteristics for the heating season in selected cities (own elaboration based on [20]).

\begin{tabular}{|c|c|c|c|c|}
\hline $\begin{array}{l}\text { Group of Climatic } \\
\text { Conditions }\end{array}$ & City & $\begin{array}{l}\text { The Energy of Solar Radiation on } \\
\text { the Plane with the Window } S \\
\text { Orientation } \Sigma I_{i}\left(\mathrm{kWh} /\left(\mathrm{m}^{2} \cdot \text { Month }\right)\right)\end{array}$ & $\begin{array}{l}\text { The Average Monthly } \\
\text { External Temperature } \\
\qquad \theta_{e}\left({ }^{\circ} \mathrm{C}\right)\end{array}$ & $\begin{array}{c}\text { The Sum of Hours of } \\
\text { the Heating Season } \\
\qquad \Sigma t_{m} \text { (h) }\end{array}$ \\
\hline $\mathrm{I}$ & Szczecin & $48,188.5$ & 4.49 & 5808 \\
\hline II & Lodz & $46,763.7$ & 2.70 & 5328 \\
\hline III & Zakopane & $63,734.3$ & 1.99 & 6048 \\
\hline
\end{tabular}

Choosing a form of dependency is not easy, because the same results can often be approximated with different functions. In this situation, one of the possible and particularly preferred forms of function are algebraic polynomials. A particularly recommended polynomial, for the determination of which most typical experiment plans have been developed, is the second-degree polynomial. These polynomials usually approximate well the results of measurements or calculations within assumed ranges of factor variability [21].

It was assumed that the desired dependency $Y=f\left(X_{1}, X_{2}, X_{3}, X_{4}, X_{5}\right)$ could be described by the second-degree polynomial in the form:

$$
\begin{gathered}
Y=a_{0}+a_{1 \times 1}+a_{2} X_{2}+a_{3} X_{3}+a_{4} X_{4}+a_{5} X_{5}+a_{12} X_{1} X_{2}+a_{13} X_{1} X_{3}+a_{14} X_{1} X_{4}+a_{15} X_{1} X_{5}+a_{23} X_{2} X_{3}+a_{24} X_{2} X_{4}+ \\
a_{25} X_{2} X_{5}+a_{34} X_{3} X_{4}+a_{35} X_{3} X_{5}+a_{45} X_{4} X_{5}+a_{11} X_{1}^{2}+a_{22} X_{2}^{2}+a_{33} X_{3}^{2}+a_{44} X_{4}{ }^{2}+a_{55} X_{5}^{2},
\end{gathered}
$$

To obtain data for the description of this dependency, a 5-factorial calculation experiment was carried out according to the second-degree plan. A compositional symmetrical three-level plan, consisting of 26 trials, was applied [21,22]. The chosen plan allows a mathematical model to be developed on the basis of the collected results in the form of a second-degree polynomial. Such a plan foresees three levels of factors: lower $(-1)$, medium $(0)$, and upper (+1). For the calculation of the $Y_{i}$ value in 26 lines of the plan, the author's program developed in Microsoft Excel was used.

Each of the considered factors were adopted at three levels corresponding to the maximum values specified in Polish regulations in force since 2014, 2017, and 2021 (Table 1). For factors $X_{1}$ and $X_{2}$, this range turned out to be narrow and was only $0.03 \mathrm{~W} /\left(\mathrm{m}^{2} \mathrm{~K}\right)$. The range for other factors was larger $\left.\left(0.2 \mathrm{~W} / \mathrm{m}^{2} \mathrm{~K}\right)\right)$, yet $U_{i}$ values accepted in legal requirements for the above periods were adopted. Such shaped ranges of factor variability allowed the authors to check the sensitivity of the tested function and obtain useful information for persons developing regulations on justifying the value of the $U_{i C(\max )}$ coefficients tested before approving the requirements for thermal protection of buildings in subsequent years.

Thus, selected factors were adopted at levels (Table 5): $X_{1}: 0.20(-1), 0.23(0), 0.26(+1)$; $X_{2}$ : 0.15(-1), 0.18(0), 0.21(+1); $X_{3}$ : 0.90(-1), 1.10(0), 1.30(+1); $X_{4}$ : 1.10(-1), 1.30(0), 1.50(+1); and $X_{5}: 1.30(-1), 1.50(0), 1.70 \mathrm{~W} /\left(\mathrm{m}^{2} \mathrm{~K}\right)(+1)$. The principle of experimental planning regarding the symmetrical ranges of variability for all factors forced the authors to deviate from the maximum values according to the Regulation on the Technical Conditions of 0.25 $\left(X_{1}=+0.6667\right)$ and $0.20\left(X_{2}=+0.6667 \mathrm{~W} /\left(\mathrm{m}^{2} \mathrm{~K}\right)\right)$ and change them at 0.26 and $0.21 \mathrm{~W} /\left(\mathrm{m}^{2} \mathrm{~K}\right)$, respectively. However, this did not pose any problem with modeling, because the new increased range covers previous values.

Table 5. Natural and standardized values of selected factors.

\begin{tabular}{cccccc}
\hline \multirow{2}{*}{ Factor Level $\dot{X}_{i}$} & $U_{\mathbf{1}}\left(X_{\mathbf{1}}\right)$ & $U_{\mathbf{2}}\left(X_{\mathbf{2}}\right)$ & $U_{\mathbf{3}}\left(X_{\mathbf{3}}\right)$ & $U_{\mathbf{4}}\left(\boldsymbol{X}_{\mathbf{4}}\right)$ & $U_{\mathbf{5}}\left(\boldsymbol{X}_{\mathbf{5}}\right)$ \\
\cline { 2 - 5 } & 0.20 & 0.15 & 0.90 & 1.10 & 1.30 \\
bottom $(-1)$ & 0.23 & 0.18 & 1.10 & 1.30 & 1.50 \\
middle (0) & 0.26 & 0.21 & 1.30 & 1.50 & 1.70 \\
upper (+1) & 0.03 & 0.03 & 0.20 & 0.20 & 0.20 \\
\hline
\end{tabular}


The above-mentioned natural values of factors $\dot{X}_{1}, \dot{X}_{2}, \dot{X}_{3}, \dot{X}_{4}, \dot{X}_{5}$, and the corresponding standardized values (in brackets) of normed values $X_{1}, X_{2}, X_{3}, X_{4}, X_{5}$ are presented in Table 5. The transition from natural $\dot{X}_{i}$ to normative values $X_{i}$ [22] is expressed by the Equation (11):

$$
X_{i}=\left[2 \dot{X}_{i}-\left(\dot{X}_{i m a x}+\dot{X}_{i m i n}\right)\right] /\left(\dot{X}_{i m a x}-\dot{X}_{\text {imin }}\right),
$$

where $\dot{X}_{i}, \dot{X}_{i, \max }$, and $\dot{X}_{i, \min }$ are the current, maximum, and minimum natural values of the $i$-th factor, respectively.

Other input variables were adopted at a constant level. Geometrical parameters characterizing the building's housing and usable area as well as materials and technical solutions used in the building are described in Section 2.2. Climatic conditions in calculating $E U_{H}$ of the tested building were assumed for Szczecin $\left(E U_{H I}\right)$, Lodz $\left(E U_{H I I}\right)$, and Zakopane $\left(E U_{H I I I}\right)$.

Based on the results of the $E U_{H I}, E U_{H I I}, E U_{H I I I}$ calculations (Table 6), using the method of least squares [22], three mathematical models were developed in the form of regression equations for the dependence of $Y=f\left(X_{1}, X_{2}, X_{3}, X_{4}, X_{5}\right)$ :

Table 6. Planning matrix and calculation results of $E U_{H I}\left(Y_{I, i}\right), E U_{H I I}\left(Y_{I I . i}\right), E U_{H I I I}\left(Y_{I I I, i}\right)$.

\begin{tabular}{|c|c|c|c|c|c|c|c|c|}
\hline \multirow{2}{*}{ No } & \multirow{2}{*}{$X_{1}$} & \multirow{2}{*}{$X_{2}$} & \multirow{2}{*}{$X_{3}$} & \multirow{2}{*}{$X_{4}$} & \multirow{2}{*}{$X_{5}$} & $E U_{H I}\left(Y_{I, i}\right)$ & $E U_{H I I}\left(Y_{I I, i}\right)$ & $E U_{H I I I}\left(Y_{I I I, i}\right)$ \\
\hline & & & & & & \multicolumn{3}{|c|}{$\left(\mathrm{kWh} /\left(\mathrm{m}^{2}\right.\right.$ year $\left.)\right)$} \\
\hline 1 & -1 & -1 & -1 & -1 & +1 & 43.2 & 48.0 & 57.6 \\
\hline 2 & +1 & -1 & -1 & -1 & -1 & 47.6 & 52.7 & 63.2 \\
\hline 3 & -1 & +1 & -1 & -1 & -1 & 45.9 & 50.9 & 61.1 \\
\hline 4 & +1 & +1 & -1 & -1 & +1 & 52.2 & 57.6 & 69.1 \\
\hline$\ldots$ & $\ldots$ & $\ldots$ & $\ldots$ & $\ldots$ & $\ldots$ & $\ldots$ & $\ldots$ & $\ldots$ \\
\hline 23 & 0 & 0 & 0 & -1 & 0 & 49.7 & 54.9 & 66.0 \\
\hline 24 & 0 & 0 & 0 & +1 & 0 & 51.0 & 56.2 & 67.5 \\
\hline 25 & 0 & 0 & 0 & 0 & -1 & 49.9 & 55.1 & 66.2 \\
\hline 26 & 0 & 0 & 0 & 0 & +1 & 50.8 & 56.1 & 67.3 \\
\hline
\end{tabular}

For Szczecin:

$\hat{Y}_{I}=50.35+2.69 X_{1}+1.84 X_{2}+2.54 X_{3}+0.61 X_{4}+0.46 X_{5}+0.02 X_{1} X_{2}+0.02 X_{1} X_{3}+0.02 X_{2} X_{3}$,

For Lodz:

$\hat{Y}_{I I}=55.57+2.88 X_{1}+1.95 X_{2}+2.69 X_{3}+0.64 X_{4}+0.49 X_{5}+0.01 X_{1} X_{2}+0.03 X_{1} X_{3}+0.01 X_{2} X_{3}$,

For Zakopane:

$\hat{Y}_{I I I}=66.74+3.46 X_{1}+2.36 X_{2}+3.26 X_{3}+0.78 X_{4}+0.59 X 5+0.03 X_{1} X_{2}+0.05 X_{1} X_{3}+0.03 X_{2} X_{3}$,

The literature recommends using standard regression analysis procedures to assess the accuracy of mathematical models, which the authors carefully followed. Because deterministic models are characterized by mutually unambiguous compatibility between the external interaction and the reaction to this impact, only one experiment was performed at each point of the plan. Then, in the absence of repetition and variance of measurement inaccuracies, the adequacy of the obtained equation according to [23] can be assessed by comparing the variances of the mean $S^{2}$ and the residual variance $S^{2}{ }_{r}$ calculated according to the Equations (15) and (16):

$$
\begin{gathered}
S^{2}{ }_{y}=\Sigma\left(Y_{i}-\bar{Y}\right)^{2} /(N-1), \\
S_{r}^{2}=\Sigma\left(\hat{Y}_{i}-Y_{i}\right)^{2} /\left(N-N_{b}\right),
\end{gathered}
$$

where $N$ is number of calculations and $N_{b}$ is number of coefficients in the regression equation. 
The Fischer criterion was applied for testing, which shows the reduction in spread with respect to the regression equation compared to the average spread [22]:

$$
F=S^{2}{ }_{y}\left(f_{1}\right) / S^{2} r\left(f_{2}\right),
$$

where $f_{1}$ and $f_{2}$ are the number of degrees of freedom: $f_{1}=(N-1)=26-1=25 ; f_{2}=(N$ $\left.-N_{b}\right)=26-21=5$.

The regression equation describes the results of calculations adequately if the value of $F$ is much greater than the tabular value $F_{t}$ at the level of significance $\mathrm{p}$ and degrees of freedom $f_{1}$ and $f_{2}$.

Calculations show that for model (12), $F_{I}=12.7361 / 0.0014=9079.1726$; for model (13), $F_{I I}=14.3381 / 0.0005=28,676.2000$; and for model $(14), F_{I I I}=20.9960 / 0.0016=13,497.4385$. Tabular value $F_{t}=F_{0.05 ; 25 ; 5}=4.525$ [23]. So, the values of $F_{I}, F_{I I}, F_{I I I}$ many times exceed $F_{t}$, which means that the models are adequate. Their high quality is also confirmed by the coefficient of determination at the level of $R^{2}=0.9999$.

The significance of coefficients in Equations (12)-(14) was also checked. Testing was performed using the $t$-criterion. Because at each point of the plan there is one result without repeats, the approach described in [23] was used, according to which, for each coefficient $t_{j}$ $=\left|b_{j}\right| / S_{b j}$, was calculated, where $b_{j}$ is the values of coefficients of the regression equation and $S_{b j}$ is the standard deviation of the $j$-th coefficient. To determine $S_{b j}$, the residual variance $S_{r}{ }^{2}$ was used based on the sum of squared deviations $\left(\hat{Y}_{i}-Y_{i}\right)^{2}$. The values were compared with the critical value of $t_{0.05 ; 5}=2.02$ [22]. If $t_{j}<t_{0.05 ; 5}$, the coefficient was considered irrelevant. After the removal of nine irrelevant factors $\left(a_{14}, a_{15}, a_{24}, a_{25}, a_{34}, a_{35}\right.$, $\left.a_{45}, a_{11}, a_{22}, a_{33}, a_{44}, a_{55}\right)$, the final form of Equations (12)-(14) with $k+1=9$ coefficients was adopted. After testing and analyzing the results, the models were considered useful for further analysis.

It should be noted that each of the mathematical models $(12 \div 14)$ was developed on the basis of 26 computational trials. However, each of these models describes the entire factor space, a full review of which, with the assumed range of factor change, would require obtaining information by calculating $3^{5}=243$ trials. The most important advantage of the models is their suitability as a tool for forecasting the value of the annual energy demand index at any point in the factor area, which was used in the following analysis. This confirms the high efficiency of the application of the mathematical modeling method.

\subsection{Methods for Assessing Savings in Heating Costs, Emissions, and Perceptible Temperature in} a Building

The financial savings are associated with the reduction of the index of annual usable energy demand for heating of a selected residential building after the tightening of the required thermal transmittance coefficient values. According to the algorithms in [18], the demand for final energy $\left(Q_{k, H}\right)$ was determined on the basis of Equation (18) and the cost of heating $\left(K_{H}\right)$ according to Equation (20):

$$
\begin{gathered}
Q_{k, H}=Q_{H, n d} / \eta_{H, t o t}, \\
\eta_{H, t o t}=\eta_{H, g} \eta_{H, e} \eta_{H, d} \eta_{H, s}, \\
K_{H}=Q_{k, H} O_{z},
\end{gathered}
$$

Limiting the negative impact on the environment of the tested building was possible by reducing harmful emissions $(\Delta E)$ from combustion in fuels, associated with reducing its energy demand for heating after tightening the $U_{C(\max )}$ requirements. Emissions were determined from Equation (21):

$$
\Delta E=\Delta O_{k, H} W E_{H}
$$


The adopted average in Poland unit price of $1 \mathrm{kWh}$ of thermal energy for various fuel types and the average annual efficiency of the heating system are presented in Table 7.

Table 7. The seasonal average efficiency of the heating system [18] and unit price of $1 \mathrm{kWh}$ of thermal energy for various fuel types (own elaboration based on [24-26]).

\begin{tabular}{ccccccc}
\hline \multirow{2}{*}{ Fuel Type } & \multicolumn{5}{c}{ The Seasonal Average Efficiency } & \multirow{2}{*}{ Unit Prices $\boldsymbol{O}_{\boldsymbol{z}}$ (EUR/kWh) } \\
\cline { 2 - 5 } & $\eta_{\boldsymbol{H}, \boldsymbol{g}}$ & $\eta_{\boldsymbol{H}, \boldsymbol{e}}$ & $\eta_{\boldsymbol{H}, \boldsymbol{d}}$ & $\eta_{\boldsymbol{H}, \boldsymbol{s}}$ & $\eta_{\boldsymbol{H}, \boldsymbol{t o t}}$ & \\
\hline Natural gas & 0.94 & 0.89 & 0.96 & 1.00 & 0.80 & 0.0687 \\
Heating oil & 0.94 & 0.89 & 0.96 & 1.00 & 0.80 & 0.0344 \\
Coal & 0.82 & 0.89 & 0.96 & 1.00 & 0.70 & 0.0336 \\
Biomass & 0.70 & 0.89 & 0.96 & 1.00 & 0.62 & 0.0345 \\
Electricity & 0.99 & 0.89 & 1.00 & 1.00 & 0.93 & 0.1265 \\
\hline
\end{tabular}

In addition, it was decided to analyze the impact of the increasingly stringent requirements for the thermal transmittance coefficient of building envelope on the perceptible temperature in rooms. This parameter influencing thermal comfort is one of the main ones responsible for high IEQ levels.

In the article, first of all, the minimum temperatures on the internal surface of the building envelope in the field (1-D) and in the place of connection between two partitions in the field (2-D) were determined: the external wall in the corner, the connection between the external wall and the roof, and the connection between the external wall and the flat roof, using the TRISCO-KOBRU 86 computer software (used for calculations of stationary heat flow). The following boundary conditions were assumed: heat transfer resistance on the internal surface of the partition $R_{s i}=0.13\left(\mathrm{~m}^{2} \mathrm{~K}\right) / \mathrm{W}$ for frames and glazing and $R_{s i}=0.25\left(\mathrm{~m}^{2} \mathrm{~K}\right) / \mathrm{W}$ for the other cases (including radiation and convection), heat transfer resistance on the external surface of the partition $R_{s e}=0.04\left(\mathrm{~m}^{2} \mathrm{~K}\right) / \mathrm{W}$, and the temperature of external air and internal air according to Table 8. Boundary conditions were established in accordance with the recommendations of International Standard [27].

Table 8. Internal and external air temperature in the analyzed variants [20].

\begin{tabular}{cccc}
\hline & $\begin{array}{c}\text { Lodz (III Climate } \\
\text { Zone of Poland) }\end{array}$ & $\begin{array}{c}\text { Szczecin (I Climate } \\
\text { Zone of Poland) }\end{array}$ & $\begin{array}{c}\text { Zakopane (V Climate Zone } \\
\text { of Poland) }\end{array}$ \\
\hline$\theta_{i}\left({ }^{\circ} \mathrm{C}\right)$ & 20 & 20 & 20 \\
$\theta_{e}\left({ }^{\circ} \mathrm{C}\right)$ & -20 & -16 & -24 \\
$\left.\theta_{e}^{*}\right)\left({ }^{\circ} \mathrm{C}\right)$ & -1.0 & -0.2 & -3.0 \\
\hline$\left.\theta_{e}^{*}\right)$ - the lowest a capita in Poland amounted to 8.36 t and were higher 2 months.
\end{tabular}

Specified minimum temperatures on the internal surface of partition in fields 1-D and 2-D were used for calculating the average temperature of the internal surface of walls and the temperature perceptible in the building.

Assuming that in the winter period, i.e., during the heating period, the influence of humidity and air velocity on the feeling of thermal comfort in the rooms is insignificant, the determining factors are the air temperature and the average surface temperature of the surrounding building envelope. Assuming that the air is stationary, the perceptible temperature $\left(T_{M}\right)$ can be determined using the Missenard method [28,29] from the Equation (22):

$$
T_{M}=0.5 \cdot \theta_{i}+0.5 \cdot \theta_{r}
$$

where $\theta_{i}$ is air temperature in the room and $\theta_{r}$ is the average temperature of surrounding surfaces.

\section{Result and Discussion}

The possibility of practical application of the developed models can be shown in the following example. We assume that we want to calculate the index of annual usable energy 
demand for heating of a selected residential building (Figure 1) located in Zakopane for the thermal transmittance coefficients of the envelope at the level: for external walls $U_{1}=0.20$; flat roof $U_{2}=0.165$; balcony windows and doors $U_{3}=1.10$; roof windows $U_{4}=1.25$; and external doors $U_{5}=1.35 \mathrm{~W} /\left(\mathrm{m}^{2} \mathrm{~K}\right)$. Other data were adopted in the study.

The solution consists of the following steps.

Step 1: We calculate the normalized values of factors $X_{i}$ according to the Equation (11):

$$
\begin{gathered}
X_{1}=[2 \times 0.20-(0.26+0.20)] /(0.26-0.20)=-1.0 \\
X_{2}=[2 \times 0.165-(0.21+0.15)] /(0.21-0.15)=-0.50 \\
X_{3}=[2 \times 1.1-(1.3+0.9)] /(1.3-0.9)=0 \\
X_{4}=[2 \times 1.25-(1.5+1.1)] /(1.5-1.1)=-0.25 \\
X_{5}=[2 \times 1.35-(1.7+1.3)] /(1.7-1.3)=-0.75
\end{gathered}
$$

Step 2: We calculate the index of annual usable energy demand for heating of a selected residential building according to the model (14):

$$
\begin{gathered}
\hat{Y}_{I I I}=66.74+3.46(-1)+2.36(-0.5)+3.26 .0+0.78(-0.25)+0.59(-0.75) \\
+0.03(-1)(-0.5)+0.05 \cdot(-1) \cdot 0+0.03 \cdot(-0.5) \cdot 0=61.47 \mathrm{kWh} /\left(\mathrm{m}^{2} \text { year }\right)
\end{gathered}
$$

The impact of the researched factors on the index of the annual usable energy demand for the heating of a selected building was determined using mathematical models (12)-(14). For better clarity, the results will be discussed on natural variables.

Analyzing the developed models, it was found that in the center of multifactorial space $G_{p}$, which is characterized by $U_{i}$ values, corresponding to the current requirements for thermal protection of the envelope in Poland (from 1 January 2017), namely: $U_{1}=0.23 \mathrm{~W} /\left(\mathrm{m}^{2} \mathrm{~K}\right) ; U_{2}=0.18 \mathrm{~W} /\left(\mathrm{m}^{2} \mathrm{~K}\right) ; U_{3}=1.10 \mathrm{~W} /\left(\mathrm{m}^{2} \mathrm{~K}\right) ; U_{4}=1.30 \mathrm{~W} /\left(\mathrm{m}^{2} \mathrm{~K}\right) ;$ and $U_{5}$ $=1.50 \mathrm{~W} /\left(\mathrm{m}^{2} \mathrm{~K}\right)$, the index of annual usable energy demand for heating in selected groups of climatic conditions is as follows: for Szczecin (1st group) $E U_{H I}=50.35$; for Lodz (II group) $E U_{H I I}=55.57$; and for Zakopane (III group) $E U_{H I I I}=66.74 \mathrm{kWh} /\left(\mathrm{m}^{2}\right.$ year). As can be seen from the cited results, the size of the energy demand indicator of the same building fluctuates significantly, namely-in comparison with Szczecin-it increases by $10.4 \%$ for Lodz and by $32.6 \%$ for Zakopane. This is due to changes in various climate indicators that determine heat losses and gains in the building's heat balance (Table 4). However, the magnitude of these fluctuations, even at locations chosen by the authors randomly, is surprising and makes a strong case for the desirability of returning to the differentiation of thermal protection requirements of heated buildings in Poland. First of all, it makes sense to determine not the same for the whole country, but different levels of required values of the heat transfer coefficient of the individual building envelope, taking into account the climatic conditions of the building site.

Then, the impact of individual factors was estimated. According to the obtained models, it turned out that for each of the selected locations, when the $U_{i}$ factors change from the lower to the upper levels (Table 5), the $E U_{H}$ value increases equally: from the $U_{1}$ factor, by about $11.1 \%$; from factor $U_{2}$, by about $7.4 \%$; from factor $U_{3}$, by about $10.4 \%$; from factor $U_{4}$, by $2.4 \%$; and from factor $U_{5}$, by $1.8 \%$. The same percentage effects of factors were obtained for each of the three models.

The tightening of the required $U_{i}$ values in force since 1 January 2017, compared to the values of the previous period (from 1 January 2014) (Table 1), resulted in a reduction of the $E U_{H}$ for the analyzed building: in the first climate group, from 57.04 to $50.35 \mathrm{kWh} /\left(\mathrm{m}^{2}\right.$ year) $\left(-6.69 \mathrm{kWh} /\left(\mathrm{m}^{2}\right.\right.$ year $)$ that is $\left.11.7 \%\right)$; in group II-from 62.66 to $55.57 \mathrm{kWh} /\left(\mathrm{m}^{2}\right.$ year $)\left(-7.09 \mathrm{kWh} /\left(\mathrm{m}^{2}\right.\right.$ year $)$ that is $\left.11.3 \%\right)$ and in group III, from 75.36 to $66.74 \mathrm{kWh} /\left(\mathrm{m}^{2}\right.$ year $)\left(-8.62 \mathrm{kWh} /\left(\mathrm{m}^{2}\right.\right.$ year $)$ that is $\left.11.4 \%\right)$. Further tightening of the $U_{i}$ value (planned for 31 December 2020) compared to the values of the current period will bring a reduction in $E U_{H}$ : in the first climate group, from 50.35 to $42.77 \mathrm{kWh} /\left(\mathrm{m}^{2}\right.$ year) 
( $-7.58 \mathrm{kWh} /\left(\mathrm{m}^{2}\right.$ year) that is $\left.15.1 \%\right)$; in group II, from 55.57 to $46.97 \mathrm{kWh} /\left(\mathrm{m}^{2}\right.$ year $)$ ) $\left(-8.60 \mathrm{kWh} /\left(\mathrm{m}^{2}\right.\right.$ year $)$ that is $\left.15.5 \%\right)$; and in group III, from 66.74 to $56.40 \mathrm{kWh} /\left(\mathrm{m}^{2}\right.$ year $)$ $\left(-10.34 \mathrm{kWh} /\left(\mathrm{m}^{2}\right.\right.$ year $)$ that is $\left.11.7 \%\right)$, as shown in Figure 2. The cumulative effect from changing the level of all factors from the upper to the lower (this corresponds to the maximum allowable $U_{i}$ for the periods from 1 January 2014 and from 31 December 2020) causes a significant decrease in $E U_{H}$ (by almost $27 \%$ for each of the analyzed building locations).

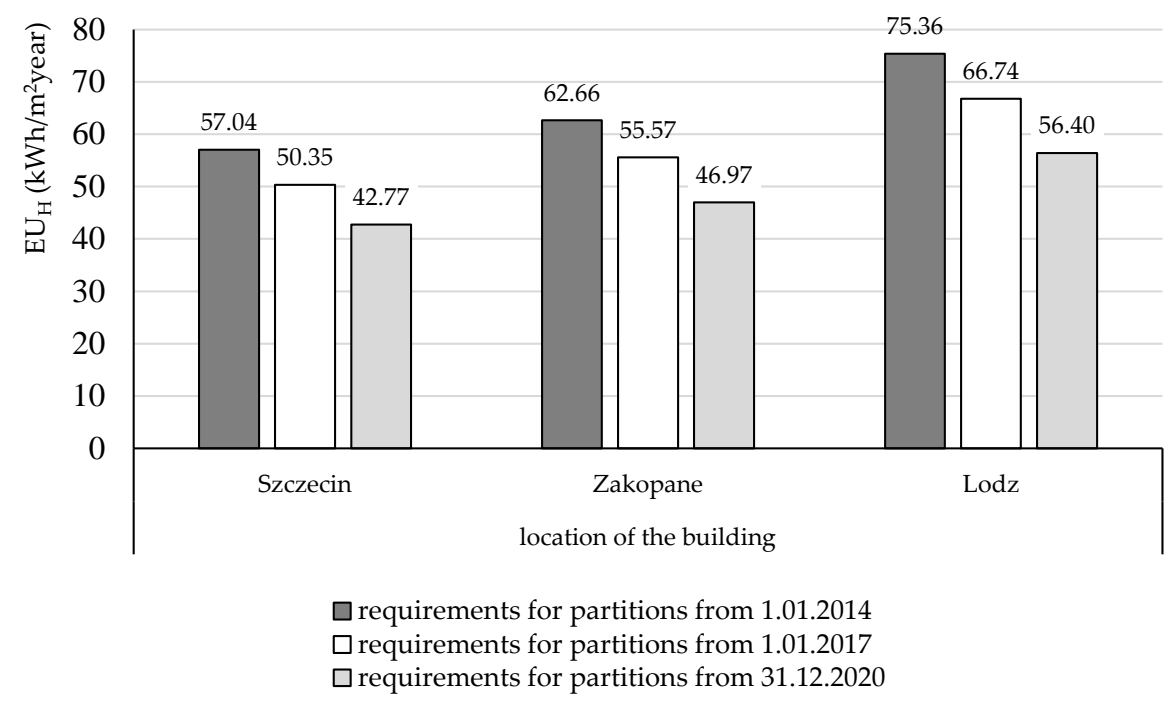

Figure 2. Changes in the index of annual usable energy demand of heating of the building $E U_{H}$ for the considered periods of application of the required $U_{i}$ values and selected groups of climatic conditions (own elaboration).

Higher financial savings (by 13.30\% in Szczecin; 21.30\% in Lodz and 19.95\% in Zakopane) were achieved when the requirements were changed from those currently in force (from 1 January 2017) to the level of future requirements (from 31 December 2020) than when the requirements that were in force in 2014-2016 were changed to the currently required level. The financial savings in each of the considered options are shown in.

Due to the highest unit price of energy (Table 7), the largest financial savings were recorded when electric heaters were used in the building (Figure 3). Despite the fact that the cheapest fuel considered was hard coal, the savings when using it were not the lowest (due to the lower efficiency of coal boiler production than a gas boiler).

As can be seen from Table 9, the highest amount of emissions was avoided, in the order of 0.84-1.30 $\mathrm{tCO}_{2}$ /year, when heating the building with electricity, followed by biomass, then hard coal and heating oil. Natural gas turned out to be the least emissive fuel, hence the reduction of $\mathrm{CO}_{2}$ emissions when using this fuel in the building was the smallest and 2.4 times lower than for electricity. 


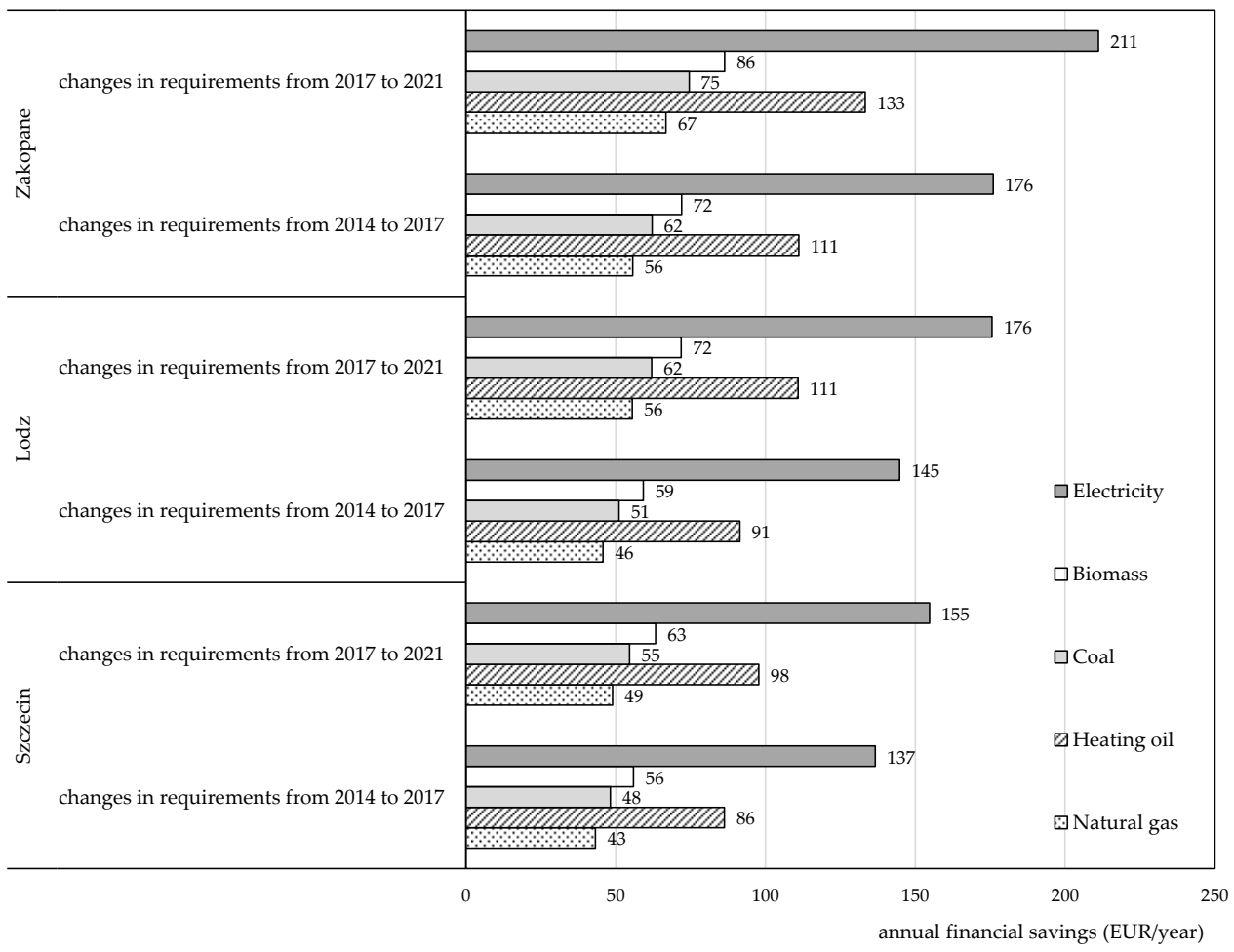

Figure 3. Annual financial savings caused by a change in the requirements for thermal protection of the building envelope (own elaboration).

Table 9. Reduction of $\mathrm{CO}_{2}$ emissions in the analyzed variants.

\begin{tabular}{|c|c|c|c|c|c|c|c|}
\hline \multirow{4}{*}{ Energy Carrier } & \multirow[b]{3}{*}{$\begin{array}{c}\text { Emission } \\
\text { Factor } \\
\mathrm{WE}_{H}, \mathrm{CO}_{2} \\
{[30,31]}\end{array}$} & \multicolumn{6}{|c|}{ Building Location } \\
\hline & & \multicolumn{2}{|c|}{ Szczecin } & \multicolumn{2}{|c|}{ Lodz } & \multicolumn{2}{|c|}{ Zakopane } \\
\hline & & $\begin{array}{c}\text { Final Energy } \\
\text { Savings } \Delta O_{k, H} \\
\text { When } \\
\text { Changing } \\
\text { Requirements: } \\
\text { from: } \\
2014 \text { to } 2017 \\
2017 \text { to } 2021\end{array}$ & $\begin{array}{c}\text { Emission } \\
\text { Reduction } \\
\Delta E C O_{2}\end{array}$ & $\begin{array}{c}\text { Final Energy } \\
\text { Savings } \Delta O_{k, H} \\
\text { When } \\
\text { Changing } \\
\text { Requirements: } \\
\text { from: } \\
2014 \text { to } 2017 \\
2017 \text { to } 2021\end{array}$ & $\begin{array}{c}\text { Emission } \\
\text { Reduction } \\
\Delta E C O_{2}\end{array}$ & $\begin{array}{c}\text { Final Energy } \\
\text { Savings } \Delta O_{k, H} \\
\text { When } \\
\text { Changing } \\
\text { Requirements: } \\
\text { from: } \\
2014 \text { to } 2017 \\
2017 \text { to } 2021\end{array}$ & $\begin{array}{c}\text { Emission } \\
\text { Reduction } \\
\Delta E C O_{2}\end{array}$ \\
\hline & $\begin{array}{c}\left(\mathrm{kgCO}_{2} / \mathrm{GJ} \text { or }\right. \\
\left.\mathrm{MgCO}_{2} / \mathrm{MWh}\right)\end{array}$ & $\begin{array}{l}\text { (GJ/Year or } \\
\text { MWh/Year) }\end{array}$ & $\left(\mathrm{kgCO}_{2} /\right.$ Year $)$ & $\begin{array}{l}\text { (GJ/Year or } \\
\text { MWh/Year) }\end{array}$ & $\left(\mathrm{kgCO}_{2} /\right.$ Year) & $\begin{array}{l}\text { (GJ/Year or } \\
\text { MWh/Year) }\end{array}$ & $\left(\mathrm{kgCO}_{2} /\right.$ Year $)$ \\
\hline $\begin{array}{l}\text { Natural gas (in } \\
\text { GJ/year) }\end{array}$ & 57.6 & $\begin{array}{l}4.52 \\
5.12\end{array}$ & $\begin{array}{l}260.35 \\
294.91\end{array}$ & $\begin{array}{l}4.79 \\
5.81\end{array}$ & $\begin{array}{c}275.9 \\
334.66\end{array}$ & $\begin{array}{l}5.82 \\
6.98\end{array}$ & $\begin{array}{l}335.23 \\
402.05\end{array}$ \\
\hline $\begin{array}{l}\text { Heating oil (in } \\
\text { GJ/year) }\end{array}$ & 77.4 & $\begin{array}{l}4.52 \\
5.12\end{array}$ & $\begin{array}{l}349.85 \\
396.29\end{array}$ & $\begin{array}{l}4.79 \\
5.81\end{array}$ & $\begin{array}{l}370.75 \\
449.69\end{array}$ & $\begin{array}{l}5.82 \\
6.98\end{array}$ & $\begin{array}{l}450.47 \\
540.25\end{array}$ \\
\hline $\begin{array}{l}\text { Coal (in } \\
\text { GJ/year) }\end{array}$ & 97.5 & $\begin{array}{l}5.16 \\
5.85\end{array}$ & $\begin{array}{l}503.10 \\
570.38\end{array}$ & $\begin{array}{l}5.47 \\
6.64\end{array}$ & $\begin{array}{c}533.33 \\
647.4\end{array}$ & $\begin{array}{l}6.65 \\
7.98\end{array}$ & $\begin{array}{l}648.38 \\
778.05\end{array}$ \\
\hline Biomass (in & 112 & $\begin{array}{l}5.83 \\
6.61\end{array}$ & $\begin{array}{l}652.96 \\
740.32\end{array}$ & $\begin{array}{l}6.18 \\
7.50\end{array}$ & $\begin{array}{c}692.16 \\
840\end{array}$ & $\begin{array}{l}7.51 \\
9.01\end{array}$ & $\begin{array}{c}841.12 \\
1009.12\end{array}$ \\
\hline GJ/rok) & $0^{1}$ & $\begin{array}{l}5.83 \\
6.61\end{array}$ & $\begin{array}{l}0 \\
0\end{array}$ & $\begin{array}{c}6.18 \\
7.5\end{array}$ & $\begin{array}{l}0 \\
0\end{array}$ & $\begin{array}{l}7.51 \\
9.01\end{array}$ & $\begin{array}{l}0 \\
0\end{array}$ \\
\hline $\begin{array}{l}\text { Electricity (in } \\
\text { MWh/year) }\end{array}$ & 0.765 & $\begin{array}{l}1.08 \\
1.22\end{array}$ & $\begin{array}{l}826.2 \\
933.3\end{array}$ & $\begin{array}{l}1.14 \\
1.39\end{array}$ & $\begin{array}{c}872.1 \\
1063.35\end{array}$ & $\begin{array}{l}1.39 \\
1.67\end{array}$ & $\begin{array}{l}1063.35 \\
1277.55\end{array}$ \\
\hline
\end{tabular}

${ }^{1}$ The unit emission level at the Polish building certification system [30]. 
In the Polish building certification system, the emission factor for biomass is 0 $\mathrm{kgCO}_{2} / \mathrm{GJ}$ (in accordance with the assumptions of the EU Emissions Trading System [30]). This approach makes it impossible to determine the ecological effect (reduction of $\mathrm{CO}_{2}$ emissions) caused by the improvement of the energy quality of the building associated with increasing the insulation of the building envelope. As shown in Table 9, emissions from burning this type of fuel are much higher than in the case of natural gas and oil and only half that of coal. Assuming that the building will be inhabited by four people, the $\mathrm{CO}_{2}$ reduction associated with the tightening of the required thermal insulation of building envelope, from the currently in force in Poland (from 1 January 2017) to the future one (from 1 January 2020), can range from $0.074 \mathrm{tCO}_{2} / \mathrm{cap} /$ year when heating a building located in Szczecin with fuel oil, up to $0.319 \mathrm{tCO}_{2} / \mathrm{cap} /$ year when heating the building with electricity in Zakopane. This represents, respectively, $0.88 \%$ and $3.82 \%$ of the current annual $\mathrm{CO}_{2}$ emissions per capita in Poland. Figure 4 shows the reduction of $\mathrm{CO}_{2}$ per capita emissions in each of the analyzed variants.

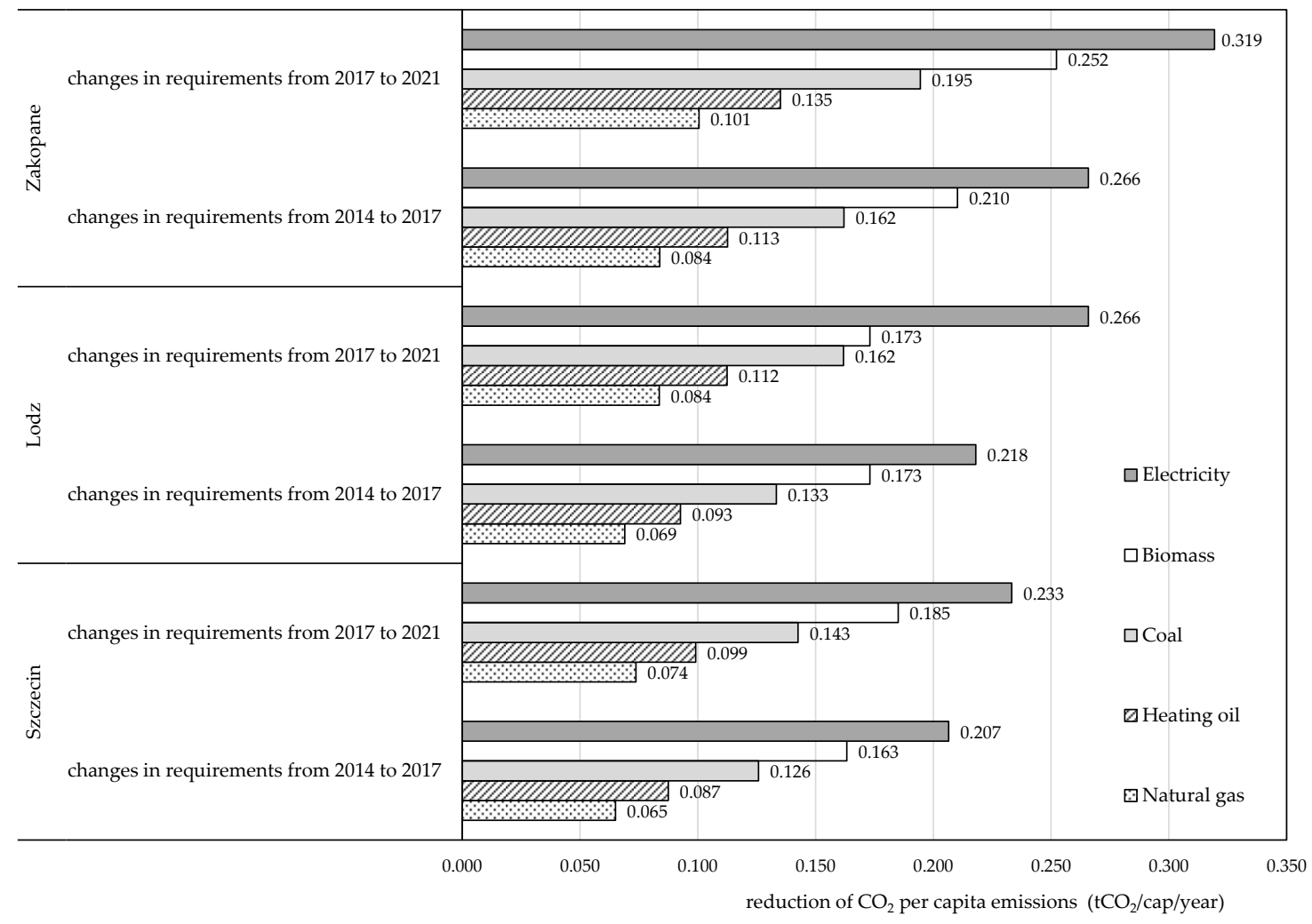

Figure 4. Reduction of $\mathrm{CO}_{2}$ per capita emissions in the analyzed variants (own elaboration).

However, it is not only carbon dioxide that affects the quality of the environment. The article also determines the reduction of emissions of main air pollutants in Poland $\mathrm{SO}_{2}$ and $\mathrm{NO}_{\mathrm{x}}$ ) as a result of changes in the required values of the thermal transmittance coefficient in the building envelope. The results of the calculations are presented in Table 10. 
Table 10. Reduction of $\mathrm{SO}_{2}$ and $\mathrm{NO}_{\mathrm{x}}$ emissions in the analyzed variants.

\begin{tabular}{|c|c|c|c|c|c|c|c|c|}
\hline \multirow{4}{*}{$\begin{array}{l}\text { Energy } \\
\text { Carrier }\end{array}$} & \multirow{3}{*}{\multicolumn{2}{|c|}{$\begin{array}{l}\text { Emission Factor } \\
\qquad W E_{H}[31-33]\end{array}$}} & \multicolumn{6}{|c|}{ Building Location } \\
\hline & & & \multicolumn{2}{|c|}{ Szczecin } & \multicolumn{2}{|c|}{ Lodz } & \multicolumn{2}{|c|}{ Zakopane } \\
\hline & & & \multicolumn{6}{|c|}{$\begin{array}{l}\text { Emission Reduction } \Delta E \text { (g/Year) } \\
\text { When Changing Requirements from: } \\
\qquad \begin{array}{c}2014 \text { to } 2017 \\
2017 \text { to } 2021\end{array}\end{array}$} \\
\hline & $\mathrm{SO}_{2}$ & $\mathrm{NO}_{\mathbf{x}}$ & $\mathrm{SO}_{2}$ & $\mathrm{NO}_{\mathbf{x}}$ & $\mathrm{SO}_{2}$ & $\mathrm{NO}_{\mathbf{x}}$ & $\mathrm{SO}_{2}$ & $\mathrm{NO}_{\mathbf{x}}$ \\
\hline $\begin{array}{l}\text { Natural } \\
\text { gas }\end{array}$ & $0.5 \mathrm{~g} / \mathrm{GJ}$ & $50 \mathrm{~g} / \mathrm{GJ}$ & $\begin{array}{l}2.26 \\
2.56\end{array}$ & $\begin{array}{l}226 \\
256\end{array}$ & $\begin{array}{l}2.40 \\
2.91\end{array}$ & $\begin{array}{l}239.5 \\
290.5\end{array}$ & $\begin{array}{l}2.91 \\
3.49\end{array}$ & $\begin{array}{l}291 \\
349\end{array}$ \\
\hline $\begin{array}{l}\text { Heating } \\
\text { oil }\end{array}$ & $140 \mathrm{~g} / \mathrm{GJ}$ & $70 \mathrm{~g} / \mathrm{GJ}$ & $\begin{array}{l}632.8 \\
716.8\end{array}$ & $\begin{array}{l}316.4 \\
358.4\end{array}$ & $\begin{array}{l}670.6 \\
813.4\end{array}$ & $\begin{array}{l}335.3 \\
406.7\end{array}$ & $\begin{array}{l}814.8 \\
977.2\end{array}$ & $\begin{array}{l}407.4 \\
488.6\end{array}$ \\
\hline Coal & $450 \mathrm{~g} / \mathrm{GJ}$ & $165 \mathrm{~g} / \mathrm{GJ}$ & $\begin{array}{c}2322 \\
2632.5\end{array}$ & $\begin{array}{c}851.4 \\
965.25\end{array}$ & $\begin{array}{c}2461.5 \\
2988\end{array}$ & $\begin{array}{l}902.55 \\
1095.6\end{array}$ & $\begin{array}{c}2992.5 \\
3591\end{array}$ & $\begin{array}{c}1097.25 \\
1316.7\end{array}$ \\
\hline Biomass & $11 \mathrm{~g} / \mathrm{GJ}$ & $91 \mathrm{~g} / \mathrm{GJ}$ & $\begin{array}{l}64.13 \\
72.71\end{array}$ & $\begin{array}{l}530.53 \\
601.51\end{array}$ & $\begin{array}{l}67.98 \\
67.98\end{array}$ & $\begin{array}{l}562.38 \\
562.38\end{array}$ & $\begin{array}{l}82.61 \\
99.11\end{array}$ & $\begin{array}{l}683.41 \\
819.91\end{array}$ \\
\hline Electricity & $\begin{array}{c}0.681 \\
\mathrm{~kg} / \mathrm{MWh}\end{array}$ & $\begin{array}{c}0.631 \\
\mathrm{~kg} / \mathrm{MWh}\end{array}$ & $\begin{array}{l}735.48 \\
830.82\end{array}$ & $\begin{array}{l}681.48 \\
769.82\end{array}$ & $\begin{array}{l}776.34 \\
946.59\end{array}$ & $\begin{array}{l}719.34 \\
877.09\end{array}$ & $\begin{array}{c}946.59 \\
1137.27\end{array}$ & $\begin{array}{c}877.09 \\
1053.77\end{array}$ \\
\hline
\end{tabular}

The greatest amount of air pollution, and hence the reduction of emissions, was obtained when coal was burned, while the lowest was obtained when heating the building with natural gas. In the case of a building being located in Zakopane, the $\mathrm{SO}_{2}$ reduction associated with the tightening of the required thermal insulation of the building envelope, from those currently in force in Poland (from 1 January 2017) to the future ones (from 31 December 2020), may amount to nearly $3.6 \mathrm{~kg} /$ year, while the $\mathrm{NO}_{\mathrm{x}}$ reduction can reach over $1.32 \mathrm{~kg}$ /year.

The analyses carried out in the article supplement the knowledge about the energy, financial, and economic effects from changes in the required $U_{C(\max )}$ values for the external building envelope in various climatic conditions of Poland. Based on the data presented in Figures 3 and 4 and in Tables 9 and 10, it is possible to quickly predict the reduction of heating costs and emissions associated with the improvement of thermal insulation of the building envelope of a single-family house.

The results of the simulation of the surface temperature $\left(\theta_{s i}\left({ }^{\circ} \mathrm{C}\right)\right)$ of the two-layer external wall are presented in Table 11. Three variants were analyzed. In variant $\mathrm{I}$, the thermal transmittance coefficient for the wall $U=0.25 \mathrm{~W} /\left(\mathrm{m}^{2} \mathrm{~K}\right)$, in variant II: $U=0.23 \mathrm{~W} /\left(\mathrm{m}^{2} \mathrm{~K}\right)$, and in variant III: $U=0.20 \mathrm{~W} /\left(\mathrm{m}^{2} \mathrm{~K}\right)$. The observed temperature increase on the internal surface of the building envelope in the one-dimensional (1-D) field depends on the thermal resistance (the thermal transmittance coefficient of the building envelope).

Table 11. The results of the simulation of the surface temperature of the external wall in three analyzed variants.

\begin{tabular}{cccc}
\hline & \multicolumn{3}{c}{$\boldsymbol{\theta}_{\boldsymbol{s i}}\left({ }^{\circ} \mathbf{C}\right)$} \\
\cline { 2 - 4 } & Variant I & Variant II & Variant III \\
\hline$\theta_{i}=20^{\circ} \mathrm{C} ; \theta_{e}=-20^{\circ} \mathrm{C}$ & 17.58 & 17.78 & 18.05 \\
$\theta_{i}=20^{\circ} \mathrm{C} ; \theta_{e}=-1{ }^{\circ} \mathrm{C}$ & 18.73 & 18.84 & 18.98 \\
$\theta_{i}=20^{\circ} \mathrm{C} ; \theta_{e}=-16^{\circ} \mathrm{C}$ & 17.82 & 18.00 & 18.25 \\
$\theta_{i}=20^{\circ} \mathrm{C} ; \theta_{e}=-0.2{ }^{\circ} \mathrm{C}$ & 18.78 & 18.88 & 19.02 \\
$\theta_{i}=20^{\circ} \mathrm{C} ; \theta_{e}=-24^{\circ} \mathrm{C}$ & 17.34 & 17.56 & 17.86 \\
$\theta_{i}=20^{\circ} \mathrm{C} ; \theta_{e}=-3{ }^{\circ} \mathrm{C}$ & 18.61 & 18.73 & 18.88 \\
\hline
\end{tabular}

The determined values of the surface temperature of a wooden roof are presented in Table 12. In variant $\mathrm{I}$, the thermal transmittance coefficient of this building envelope $U=$ $0.20 \mathrm{~W} /\left(\mathrm{m}^{2} \mathrm{~K}\right)$, in variant II: $U=0.18 \mathrm{~W} /\left(\mathrm{m}^{2} \mathrm{~K}\right)$ and in variant III: $U=0.15 \mathrm{~W} /\left(\mathrm{m}^{2} \mathrm{~K}\right)$. 
Table 12. The results of the simulation of the surface temperature of the wooden roof in three analyzed variants.

\begin{tabular}{cccc}
\hline & \multicolumn{3}{c}{$\boldsymbol{\theta}_{\boldsymbol{s i}}\left({ }^{\circ} \mathbf{C}\right)$} \\
\cline { 2 - 4 } & Variant I & Variant II & Variant III \\
\hline$\theta_{i}=20^{\circ} \mathrm{C} ; \theta_{e}=-20^{\circ} \mathrm{C}$ & 18.06 & 18.23 & 18.50 \\
$\theta_{i}=20^{\circ} \mathrm{C} ; \theta_{e}=-1{ }^{\circ} \mathrm{C}$ & 18.98 & 19.07 & 19.21 \\
$\theta_{i}=20^{\circ} \mathrm{C} ; \theta_{e}=-16^{\circ} \mathrm{C}$ & 18.26 & 18.41 & 18.65 \\
$\theta_{i}=20^{\circ} \mathrm{C} ; \theta_{e}=-0.2^{\circ} \mathrm{C}$ & 19.03 & 19.11 & 19.24 \\
$\theta_{i}=20^{\circ} \mathrm{C} ; \theta_{e}=-24^{\circ} \mathrm{C}$ & 17.87 & 18.06 & 18.35 \\
$\theta_{i}=20^{\circ} \mathrm{C} ; \theta_{e}=-3{ }^{\circ} \mathrm{C}$ & 18.89 & 18.98 & 19.14 \\
\hline
\end{tabular}

The simulation results of the numerical calculations performed to determine the minimum temperature on the inner surface of the four most important construction joints are shown in Figures 5-7 and in Tables 13-15.

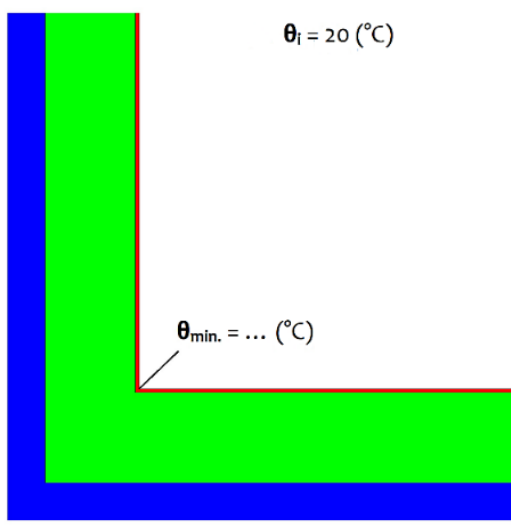

$\theta_{\mathrm{e}}=\ldots\left({ }^{\circ} \mathrm{C}\right)$

(a)

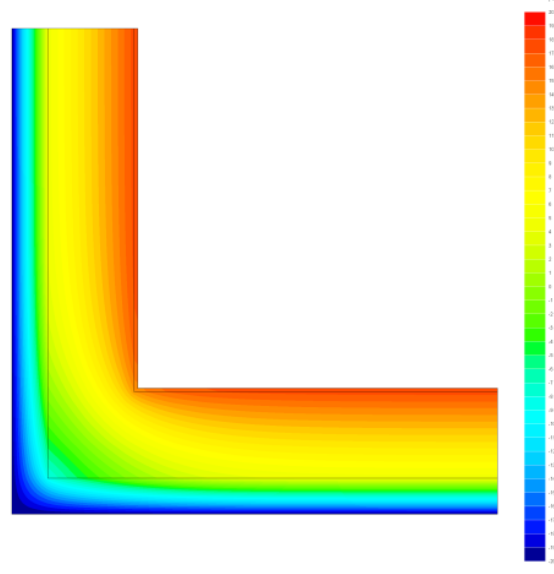

isotherms $\left(\theta_{i}=20^{\circ} \mathrm{C} ; \theta_{e}=-20^{\circ} \mathrm{C}\right)$

(c)

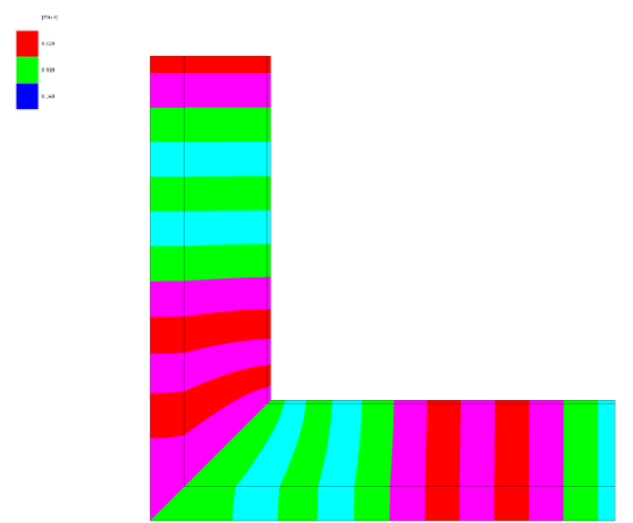

(b)

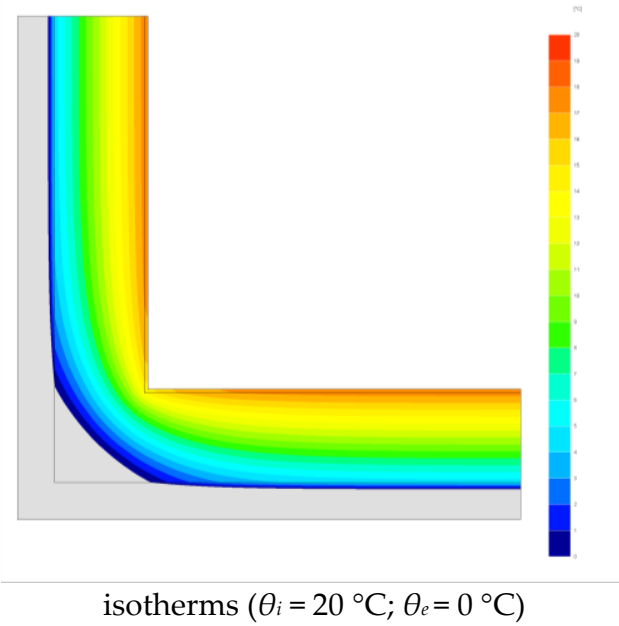

(d)

Figure 5. Graphic representation of the simulation results of numerical calculations for the corner of external walls: (a) Calculation model; (b) Heat flux lines; (c,d) Temperature distribution. 


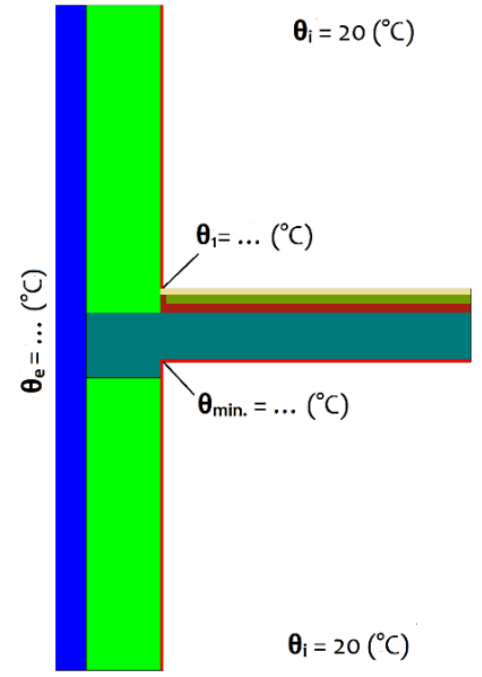

(a)

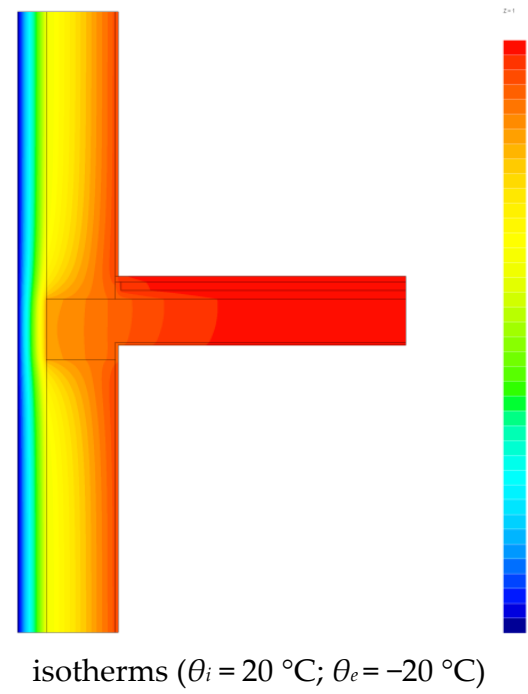

(c)

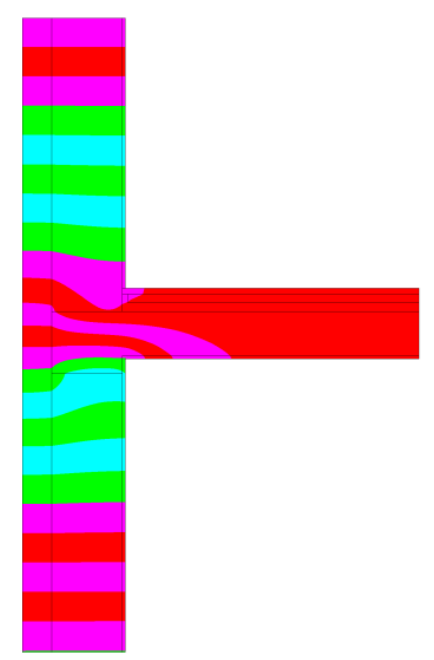

(b)

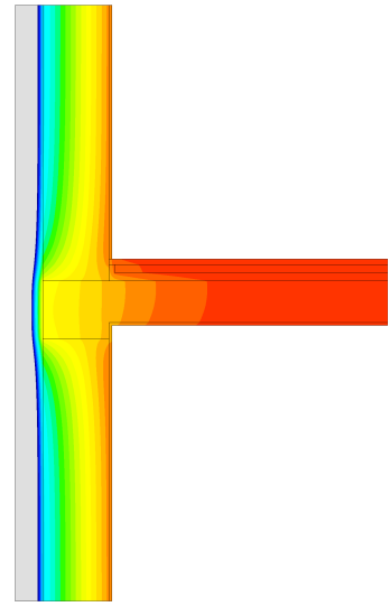

isotherms $\left(\theta_{i}=20^{\circ} \mathrm{C} ; \theta_{e}=0{ }^{\circ} \mathrm{C}\right)$

(d)

Figure 6. Graphic representation of the simulation results of numerical calculations for the junction of the external wall with the ceiling: (a) Calculation model; (b) Heat flux lines; (c), (d) Temperature distribution.

Table 13. Temperature at the corners of external walls.

\begin{tabular}{cccc}
\hline & \multicolumn{3}{c}{$\boldsymbol{\theta}_{\text {min }}\left({ }^{\circ} \mathbf{C}\right)$} \\
\cline { 2 - 4 } & Variant I & Variant II & Variant III \\
\hline$\theta_{i}=20^{\circ} \mathrm{C} ; \theta_{e}=-20^{\circ} \mathrm{C}$ & 14.56 & 14.56 & 15.38 \\
$\theta_{i}=20^{\circ} \mathrm{C} ; \theta_{e}=-1{ }^{\circ} \mathrm{C}$ & 17.14 & 17.14 & 17.58 \\
$\theta_{i}=20^{\circ} \mathrm{C} ; \theta_{e}=-16^{\circ} \mathrm{C}$ & 15.10 & 15.10 & 15.84 \\
$\theta_{i}=20^{\circ} \mathrm{C} ; \theta_{e}=-0.2^{\circ} \mathrm{C}$ & 17.25 & 17.25 & 17.67 \\
$\theta_{i}=20^{\circ} \mathrm{C} ; \theta_{e}=-24^{\circ} \mathrm{C}$ & 14.01 & 14.01 & 14.92 \\
$\theta_{i}=20^{\circ} \mathrm{C} ; \theta_{e}=-3{ }^{\circ} \mathrm{C}$ & 16.87 & 16.87 & 17.34 \\
\hline
\end{tabular}




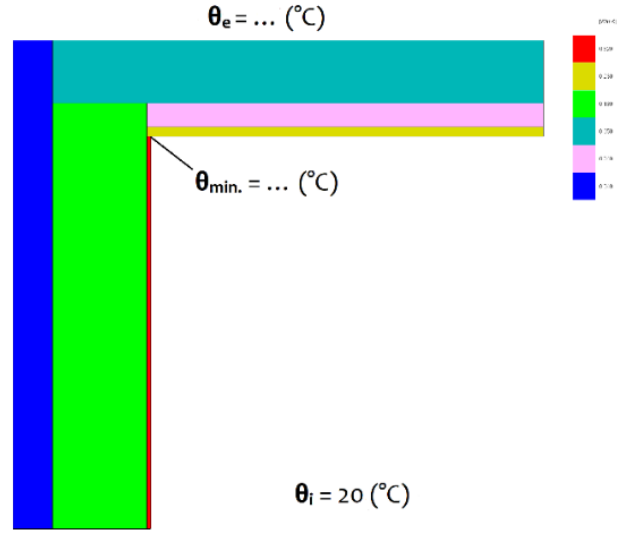

(a)

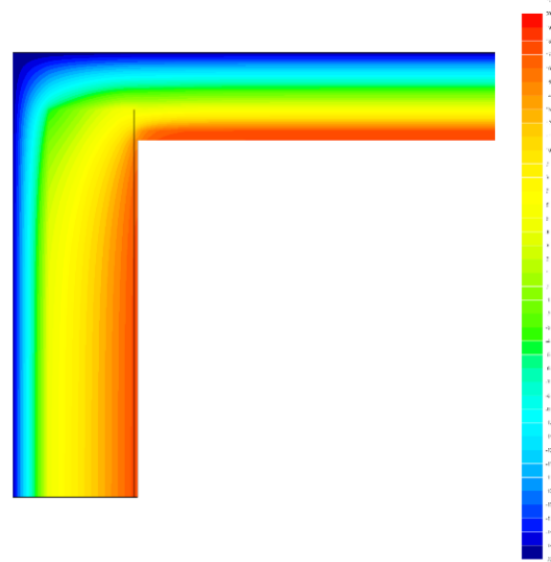

isotherms $\left(\theta_{i}=20^{\circ} \mathrm{C} ; \theta_{e}=-20^{\circ} \mathrm{C}\right)$

(c)

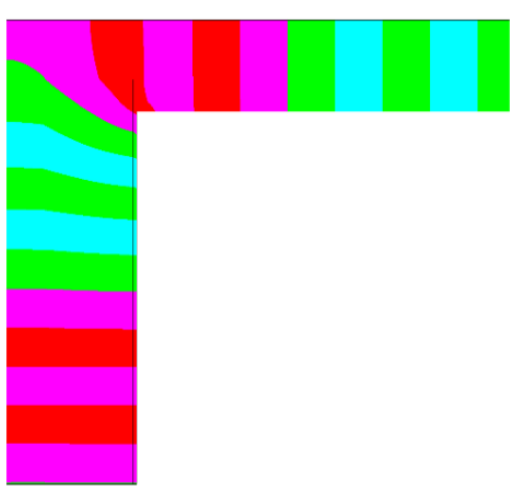

(b)

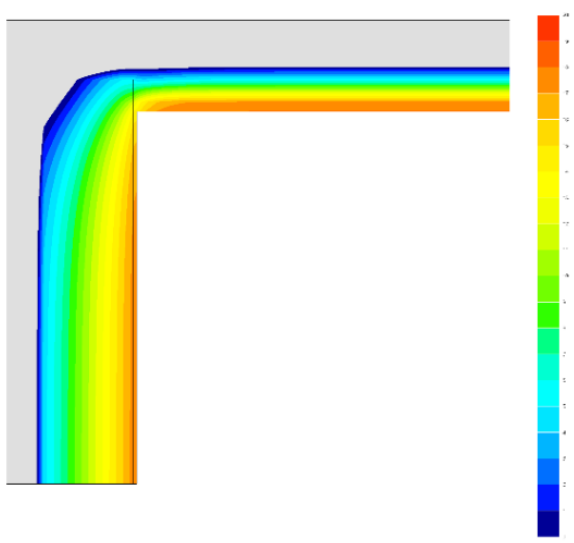

isotherms $\left(\theta_{i}=20^{\circ} \mathrm{C} ; \theta_{e}=0{ }^{\circ} \mathrm{C}\right)$

(d)

Figure 7. Graphic representation of the simulation results of numerical calculations for the junction of the external wall with the roof: (a) Calculation model; (b) Heat flux lines; (c), (d) Temperature distribution.

Table 14. Temperature at the junction of the external wall with the ceiling.

\begin{tabular}{cccc}
\hline & \multicolumn{3}{c}{$\boldsymbol{\theta}_{\min }\left({ }^{\circ} \mathbf{C}\right) / \boldsymbol{\theta}_{\mathbf{1}}\left({ }^{\circ} \mathbf{C}\right)$} \\
\cline { 2 - 4 } & Variant I & Variant II & Variant III \\
\hline$\theta_{i}=20^{\circ} \mathrm{C} ; \theta_{e}=-20^{\circ} \mathrm{C}$ & $16.55 / 18.03$ & $16.89 / 18.21$ & $17.33 / 18.46$ \\
$\theta_{i}=20^{\circ} \mathrm{C} ; \theta_{e}=-1{ }^{\circ} \mathrm{C}$ & $18.19 / 18.96$ & $18.37 / 19.06$ & $18.60 / 19.19$ \\
$\theta_{i}=20^{\circ} \mathrm{C} ; \theta_{e}=-16^{\circ} \mathrm{C}$ & $16.89 / 18.22$ & $17.20 / 18.39$ & $17.59 / 18.61$ \\
$\theta_{i}=20^{\circ} \mathrm{C} ; \theta_{e}=-0.2{ }^{\circ} \mathrm{C}$ & $18.26 / 19.00$ & $18.43 / 19.10$ & $18.65 / 19.22$ \\
$\theta_{i}=20^{\circ} \mathrm{C} ; \theta_{e}=-24{ }^{\circ} \mathrm{C}$ & $16.20 / 17.83$ & $16.58 / 18.03$ & $17.06 / 18.30$ \\
$\theta_{i}=20^{\circ} \mathrm{C} ; \theta_{e}=-3{ }^{\circ} \mathrm{C}$ & $18.02 / 18.86$ & $18.21 / 18.97$ & $18.46 / 19.11$ \\
\hline
\end{tabular}


Table 15. Temperature at the junction of the external wall with the roof.

\begin{tabular}{cccc}
\hline & \multicolumn{3}{c}{$\boldsymbol{\theta}_{\min }\left({ }^{\circ} \mathbf{C}\right)$} \\
\cline { 2 - 4 } & Variant I & Variant II & Variant III \\
\hline$\theta_{i}=20^{\circ} \mathrm{C} ; \theta_{e}=-20^{\circ} \mathrm{C}$ & 14.48 & 14.63 & 14.89 \\
$\theta_{i}=20^{\circ} \mathrm{C} ; \theta_{e}=-1{ }^{\circ} \mathrm{C}$ & 17.10 & 17.18 & 17.32 \\
$\theta_{i}=20^{\circ} \mathrm{C} ; \theta_{e}=-16^{\circ} \mathrm{C}$ & 15.03 & 15.17 & 15.40 \\
$\theta_{i}=20^{\circ} \mathrm{C} ; \theta_{e}=-0.2^{\circ} \mathrm{C}$ & 17.21 & 17.29 & 17.42 \\
$\theta_{i}=20^{\circ} \mathrm{C} ; \theta_{e}=-24^{\circ} \mathrm{C}$ & 13.93 & 14.10 & 14.38 \\
$\theta_{i}=20^{\circ} \mathrm{C} ; \theta_{e}=-3{ }^{\circ} \mathrm{C}$ & 16.83 & 16.91 & 17.06 \\
\hline
\end{tabular}

The obtained data (Tables 13-15) on the temperatures on the inner surface of the building envelope and their junctions allowed an estimation of the effects of the influence of selected factors on the parameters of room comfort in the analyzed climatic conditions.

The living room on the ground floor of the building was selected to analyze the impact of changes in the thermal insulation of the building envelope on the perceived temperature. It is a room $5.46 \mathrm{~m}$ wide, with one of the external walls without windows. The average temperature of the surrounding surfaces was calculated on the basis of the determined temperature values on the inner surface of the wall in the one-dimensional (1-D) field given in Table 11 and the temperature in the corners (Table 13) and at the junction of the external wall with the ceiling (Table 14) in a two-dimensional (2-D) field. The thermal bridge range of the analyzed joints was assumed to be $10 \mathrm{~cm}$. The calculation results of the perceptible temperature determined based on Equation (22), in different climatic zones of Poland at different levels of thermal insulation of the walls are shown in Figure 8.

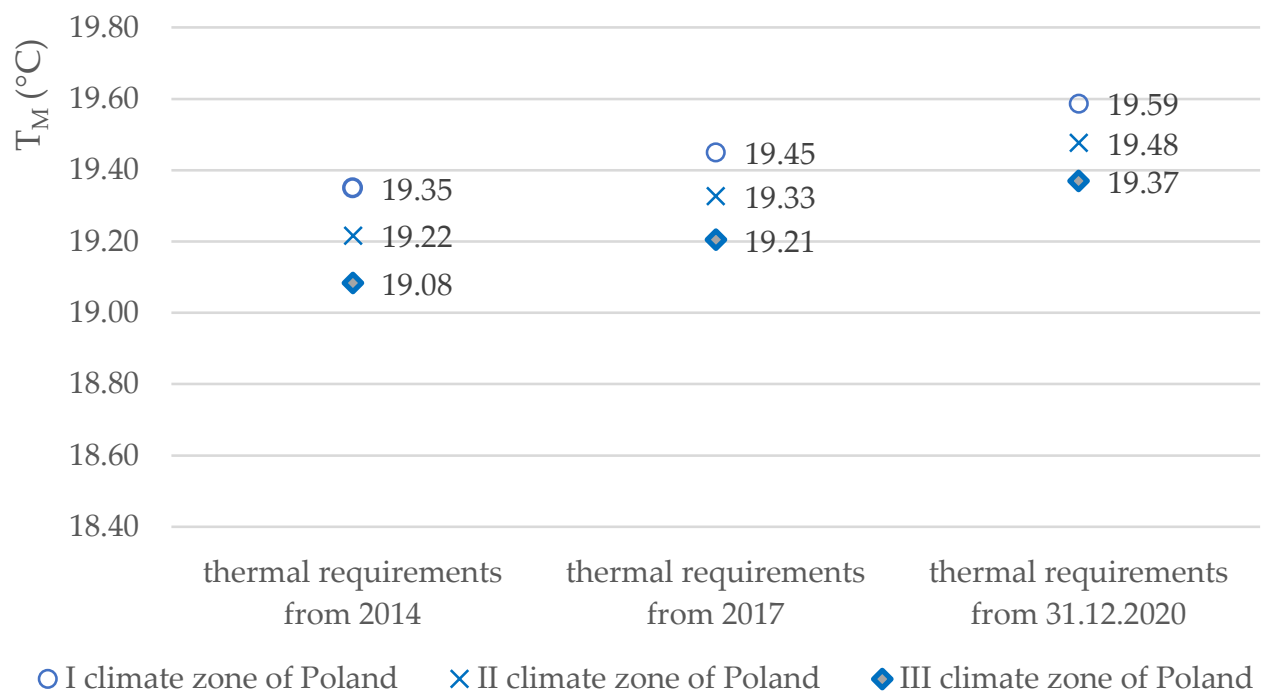

Figure 8. Changes in the perceptible temperature in the living room along with the change of the required thermal insulation of the external wall in different climatic zones of Poland (own elaboration).

The tightening of the required $U_{i}$ values in force since 1 January 2017, compared to the values of the previous period (from 1 January 2014) (Table 1), resulted in an increase in the perceptible temperature in the room by $0.10^{\circ} \mathrm{C}$ in the I group of Polish climatic conditions (i.e., by $0.50 \%$ ), in group II by $0.11^{\circ} \mathrm{C}$ (which is $0.57 \%$ ), and in group III by $0.12{ }^{\circ} \mathrm{C}$ (which constitutes $0.64 \%$ ). Further tightening of the $U_{i}$ value (from 31 December 2020) compared to the values of the current period will bring an increase in the perceptible temperature by $0.14{ }^{\circ} \mathrm{C}$ (which is $0.71 \%$ ), in group II by $0.15^{\circ} \mathrm{C}$ (which is $0.77 \%$ ), and in group III by $0.17^{\circ} \mathrm{C}$ (which is $0.86 \%$ ), as shown in Figure 8 . The cumulative effect from changing the level of the $U$ for walls from the upper to the lower (this corresponds to the maximum 
allowable $U_{i}$ for the periods from 1 January 2014 and from 31 December 2020) causes an increase in $T_{M}$ by $0.24,0.26$, and $0.29^{\circ} \mathrm{C}$ at different locations in the building (i.e., by $1.2 \%$, $1.35 \%$, and $1.50 \%$ ).

\section{Conclusions}

Changes in the required levels of thermal insulation of building envelopes, introduced in Polish legal regulations from 1 January 2014, 1 January 2017, and 1 January 2021, as an implementation of the European directive on the energy performance of buildings [1], have an impact on the reduction of energy demand, heating costs, and harmful emissions as well as parameters influencing the thermal comfort of rooms.

Developed deterministic mathematical models allowed the authors to estimate the effects of stricter thermal protection requirements of the building envelope of a singlefamily residential building on the indicator of the demand for usable energy in its three locations in Poland and on the reduction of emissions, as well as assess the financial benefits when using different heat sources in this building. Based on the analysis, three main conclusions can be drawn:

- It was found that the change in the required $U_{i, \max }$ the selected building envelopes, from the level in force from 1 January 2014 to the current one, caused a decrease in the $E U_{H}$ for the selected residential building, typical for Polish conditions and with natural ventilation, by over $11 \%$ in each of the considered locations. The change in the required $U_{i, \max }$ of the selected building envelope from the current level to the requirements from 1 January 2021 will result in a further reduction of the $E U_{H}$ by over $15 \%$. Differences in the energy demand of the same building in different locations in Poland are significant and amount to even $32.6 \%$ in the cases considered in the article. Therefore, it is reasonable to return to the approach of determining the requirements for thermal protection of heated buildings in Poland, not uniform for the whole country, but varied, taking into account the climatic conditions of the construction site.

- Annual financial savings associated with changes in the required thermal insulation of the building envelope in the years 2014-2021, depending on the fuel used in the building, range from 43 EUR for gas supplying a building located in Szczecin, up to 211 EUR in a building located in Zakopane, when heating it with electricity. The reduction of carbon dioxide emissions in this respect may reach from $0.88 \%$ to $3.89 \%$ of current annual $\mathrm{CO}_{2}$ emissions per capita in Poland.

- Increasing the thermal insulation of the walls has a slight but positive effect on the parameters of thermal comfort in rooms. The increase in the perceptible temperature resulting from the tightening of thermal requirements for external walls in Poland in the period from 2017 to 2021 ranges from $1.22 \%$ to $1.50 \%$, depending on the location of the building.

The authors plan to carry out similar tests for other types of buildings, other locations, and under different boundary conditions as well as apply this methodology to results from building energy simulation data. The information collected in this topic will provide the basis for a differentiated approach to building envelope design under varying climate conditions. This applies not only to Poland but also to other European countries that apply a similar approach to building envelope design. It also becomes justified to carry out analyses in the scope of correlation of the maximum values of thermal transmittance coefficients of the individual external building envelope with the maximum values of the index of the non-renewable primary energy demand $\left(E P_{\max }\right)$. It is also planned to investigate the influence of the factors considered in the article on the parameters of thermal comfort of rooms and the indoor environmental quality and using more detailed methods than in this paper. 
Author Contributions: Conceptualization, W.J.; methodology, W.J., K.P. and B.S.; investigation, W.J. and B.S.; validation, W.J.; writing and editing, B.S. and K.P. All authors have read and agreed to the published version of the manuscript.

Funding: The research was carried out under statute grant no. WZ/WBIIŚ/5/2019 and financed from the funds for science of the Polish Ministry of Science and Higher Education.

Conflicts of Interest: The authors declare no conflict of interest.

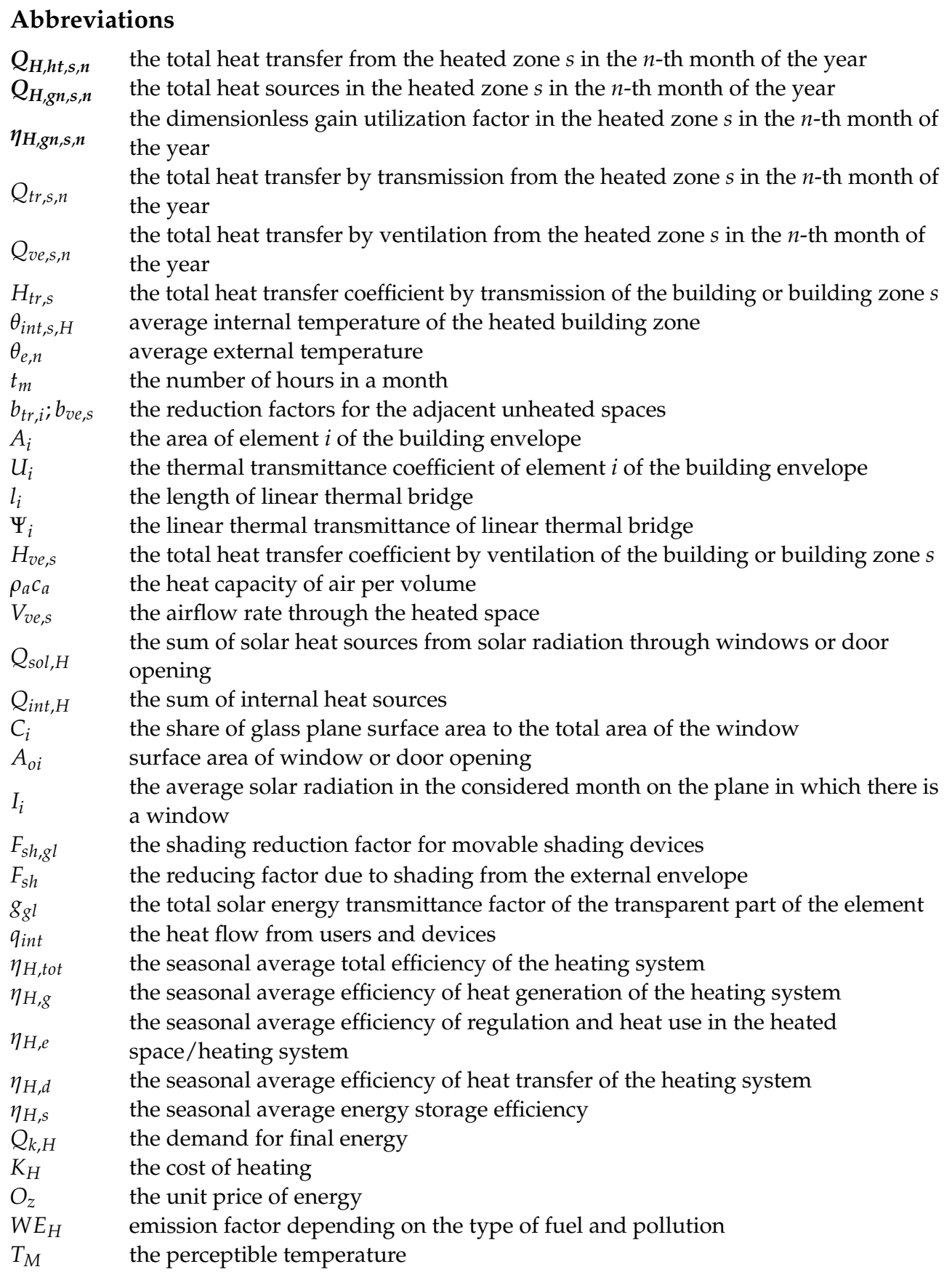

\section{References}

1. Directive 2010/31/EU of The European Parliament and of the Council of 19 May 2010 on the Energy Performance of Buildings. Available online: https:/ / eur-lex.europa.eu/legal-content/PL/ALL/?uri=CELEX\%3A32010L0031 (accessed on 28 April 2020).

2. Polish Ministry of Transport, Construction and Maritime Economy. Regulation of the Minister of Transport, Construction and Maritime Economy of 5 July 2013 on the Technical Conditions That Buildings and Their Location Should Satisfy; Polish Ministry of Transport, Construction and Maritime Economy: Warsaw, Poland, 2015. 
3. Życzyńska, A.; Cholewa, T. The modifications to the requirements on energy savings and thermal insulation of buildings in Poland in the years 1974-2021. Bud. Archit. 2015, 14, 145-154. [CrossRef]

4. United Nations Economic Commission for Europe Joint Task Force on Energy Efficiency Standards in Buildings. Mapping of Existing Energy Efficiency Standards and Technologies in Buildings in the UNECE Region; UNECE: Geneva, Switzerland, 2018. Available online: https://www.unece.org/fileadmin/DAM/hlm/Meetings/2018/09_05-07_St._Petersburg/EE_Standards_in_ Buildings_full_version.ENG.pdf (accessed on 28 April 2020).

5. D'Agostino, D.; de'Rossi, F.; Marigliano, M.; Marino, C.; Minichiello, F. Evaluation of the optimal thermal insulation thickness for an office building in different climates by means of the basic and modified "cost-optimal" methodology. J. Build. Eng. 2019, 24. [CrossRef]

6. Concerted Action Energy Performance of Buildings. Database. Available online: https://epbd-ca.eu/database-of-outputs (accessed on 28 April 2020).

7. Österreichisches Institut für Bautechnik. OIB Guidelines, Austria, OIB-330.6-026/19. Available online: https://www.oib.or.at/ de/oib-richtlinien (accessed on 25 November 2020).

8. Main Office of Building Control. Construction Market in Poland in 2018. Warsaw, Poland, 2018. Available online: https: //www.gunb.gov.pl/aktualnosc/ruch-budowlany-w-2018-r (accessed on 28 April 2020).

9. Statistics Poland. Occupied Buildings. National Census of Population and Housing 2011 in Poland; Central Statistical Office: Warsaw, Poland, 2013; p. 18.

10. Eurostat. Living Conditions in Europe; Publications Office of the European Union: Luxembourg, 2018. Available online: https: / / ec.europa.eu/eurostat/web/income-and-living-conditions/overview (accessed on 28 April 2020).

11. Ministry of Infrastructure and Development of Poland. National plan for increasing the number of nearly zero-energy buildings as required by directive 2010/31/EU on the energy performance of buildings (EPBD recast)_Poland. J. Laws Repub. Pol. 2015, 614. Available online: http://isap.sejm.gov.pl/isap.nsf/DocDetails.xsp?id=WMP20150000614 (accessed on 23 December 2020).

12. Statistics Poland. Household Energy Consumption in 2018; Central Statistical Office: Warsaw, Poland, 2019. Available online: https:/ / stat.gov.pl/obszary-tematyczne/srodowisko-energia/energia/zuzycie-energii-w-gospodarstwach-domowychw-2018-roku,12,1.html (accessed on 28 April 2020).

13. Krawczyk, D.A.; Sadowska, B. Modernization of Existing Buildings. Buildings 2020+ Constructions, Materials and Installations; Printing House of Bialystok University of Technology: Wiejska, Poland, 2019; pp. 107-129.

14. Jezierski, W.; Sadowska, B. Economic effects of changes in the required thermal insulation of building partitions in Poland. Econ. Environ. 2020, 1, 109-126.

15. Narowski, P. Energy simulations of buildings-What they are and what they are used for. Energ. Budynek 2007, 9, 4-13.

16. Statistics Poland. In Statistical Snalyses: Environment 2019; Spatial and Environmental Surveys Department: Warsaw, Poland, 2019. Available online: https:/ / stat.gov.pl/obszary-tematyczne/srodowisko-energia/srodowisko/ochrona-srodowiska-2019,1,20.html (accessed on 28 April 2020).

17. Crippa, M.; Oreggioni, G.; Guizzardi, D.; Muntean, M.; Schaaf, E.; Lo Vullo, E.; Solazzo, E.; Monforti-Ferrario, F.; Olivier, J.G.J.; Vignati, E. Fossil $\mathrm{CO}_{2}$ and GHG Emissions of All World Countries-2019 Report, EUR 29849 EN.; Publications Office of the European Union: Luxembourg, 2019; ISBN 978-92-76-11100-9. JRC117610. [CrossRef]

18. Polish Ministry of Infrastructure. Regulation of the minister of infrastructure of 27 February 2015 on the methodology for calculating the energy performance of a building or part of a building and energy performance certificates. J. Laws Repub. Pol. 2015, 376. Available online: http:/ / isap.sejm.gov.pl/isap.nsf/DocDetails.xsp?id=WDU20150000376 (accessed on 23 December 2020).

19. Gutenbaum, J. Mathematical Modeling of Systems; EXIT: Warsaw, Poland, 2003.

20. Typical Meteorological Years and Statistical Climate Data for Poland for Energy Calculations of Buildings. Available online: https: / / dane.gov.pl/dataset/797, typowe-lata-meteorologiczne-i-statystyczne-dane-klimatyczne-dla-obszaru-polski-doobliczen-energetycznych-budynkow (accessed on 28 April 2020).

21. StatSoft Electronic Statistics Textbook. Available online: https://www.statsoft.pl/textbook/stathome.html (accessed on 26 November 2019).

22. Korzyński, M. Methodology of the Experiment. Planning, Implementation, and Statistical Analysis of the Results of Technological Experiments; WNT: Warsaw, Poland, 2006.

23. Durakovic, B. Design of experiments application, concepts, examples. State Art Period. Eng. Nat. Sci. 2017, 5, 421-439.

24. Price of Electricity. Available online: http:/ / www.cena-pradu.pl/ (accessed on 14 November 2019).

25. Fuel Exchange. Available online: http://gielda-paliw.com/ogloszenia/kategoria/238/olej-opalowy (accessed on 14 November 2019).

26. Portal Krosno24. Available online: https://krosno24.pl/anonse/kategoria/21 (accessed on 14 November 2019).

27. ISO 10211:2017 Thermal Bridges in Building Construction-Heat Flows and Surface Temperatures-Detailed calculations. Available online: https:/ /www.iso.org/standard/65710.html (accessed on 14 December 2020).

28. Ickiewicz, I.; Sarosiek, W.; Ickiewicz, J. Building Physics—Selected Issues; Printing House of Bialystok University of Technology: Bialystok, Poland, 2000.

29. Dylla, A. Building Physics in Practice; PWN: Warsaw, Poland, 2015. 
30. Poland's National Inventory Report 2019. Heating Values and $\mathrm{CO}_{2}$ Emission Factors in 2017 for Reporting under the Emissions Trading System for 2019; KOBiZE: Warsaw, Poland, 2019.

31. Poland's National Inventory Report 2019. $\mathrm{CO}_{2}, \mathrm{SO}_{2}, \mathrm{NO}_{x}, \mathrm{CO}$ and Total Dust Emission Ratios for Electricity based on Information Contained in the National Database of Greenhouse Gas Emissions and Other Substances for 2018; KOBiZE: Warsaw, Poland, 2019.

32. Emissions Trading System EU ETS. Available online: https:/ / ec.europa.eu/clima/policies/ets_en (accessed on 28 April 2020).

33. EEA. EMEP/EEA Air Pollutant Emission Inventory Guidebook 2019-Part B, 1.A.4 Small Combustion; European Environment Agency; Report No 13/2019. Available online: https:/ / www.eea.europa.eu/publications/emep-eea-guidebook-2019 (accessed on 28 April 2020). 